\title{
Palaeoproterozoic Mafic magmatism in the Indian Shield: Petrologic, Geochemical and Thermal constraints on Proterozoic Mantle
}

\author{
1. National Centre for Earth Science Studies, Trivandrum - 695011, Kerala, India \\ 2. School of Earth Sciences, SRTM University, Nanded - 431606, Maharashtra, India \\ * Present address: GITAM University, Nagadenehalli, Doddaballapur Taluk, Bangalore - 561203, Karnataka, India
}

(Received : 4/03/2019; Revised accepted : 28/08/2019)

https://doi.org/10.18814/epiiugs/2020/020012

In this paper we have synthesized the published and unpublished geochemical data on the Palaeoproterozoic mafic magmatism in the Indian Shield. Palaeoproterozoic mafic magmatism is widespread in the Indian Shield; it mostly emplaced as dyke intrusions within the cratons and south Indian granulite region and as intrusives/traps in the intra-cratonic basins and the Eastern Ghat Mobile Belt. Integration of the U-Pb ages with palaeomagnetic results identified at least four discrete Palaeoproterozoic igneous events at 2.36-2.37 Ga, 2.1-2.2 Ga, 2.0-2.1 Ga 1.89-1.99 $\mathrm{Ga}$ and probably two other events at about $2.4 \mathrm{Ga}$ and $1.8 \mathrm{Ga}$. The Palaeoproterozoic magmatism across the Indian cratons seems geochemically monotonous and exclusively mafic and sub-alkalic tholeiitic basalt/basaltic andesite in composition with typical enrichment of large ion lithophile and light rare earth elements. Fractional crystallization is the dominant mechanism controlling the geochemical spectrum of the Indian Palaeoproterozoic magmas with little indications of crustal assimilation. Asthenosphere mantle is the major supplier of material for the Palaeoproterozoic igneous activity. Sub-Continental Lithosphere Mantle (SCLM) seems to be the major contributor for the enriched characteristics of the Palaeoproterozoic mafic magmas erupted in the Indian Shield. Thermal energy for the initiation of melting is likely contributed by mantle plumes although a passive rifting is not ruled out. Geochemistry of the Palaeoproterozoic mafic magmas in some way appears to have similarities to that of the end-Cretaceous Deccan basaltic magmas and do reflect plume-lithosphere interaction. The SCLM beneath the Indian Shield was possibly enriched by addition of fluids/ melts of deep mantle origin. We suggest that the major segments of the Indian SCLM were generated at around 3 Ga coinciding with a major crustal building activity in the Indian shield.

\section{Introduction}

Mafic igneous activity is an important feature of the Proterozoic Earth particularly in the stabilized Archaean cratons and may be the only significant geological event at about $2 \mathrm{Ga}$. The genesis of each pulse of igneous activity clearly constitutes a major thermal event affecting the Earth's mantle. The advent of precise U-Pb dating (e.g. LeCheminant and Heaman, 1989) is remarkable in the sense that it indicated the emplacement of Proterozoic magmatic activity took place over a very restricted time interval, which allowed drawing parallel with the Phanerozoic continental flood basalt magmatism. This implies that a large amount of thermal energy was available for melting the mantle, but it was apparently delivered quickly and periodically.

The magmas of the continental igneous units pass through thick Archaean crust before emplacement. There is always the question of the extent to which the magma compositions have been modified by processes like fractional crystallization en route, assimilation with fractional crystallization (AFC) or ponding of magmas near the Moho with melting, assimilation, storage and homogenization before emplacement. At the same time, the compositional variations in the continental igneous lithologies have potentially been explained in terms of partial melting, dynamic melting, mantle lithosphere enrichment processes or heterogeneous mantle reservoirs among others. Despite this apparent conceptual clarity, our understanding of the origin of mantle compositional heterogeneity, in particular the origin of the enriched geochemical signatures inferred from within plate igneous lithologies, remains somewhat incomplete (Hofmann and White, 1982; Sobolev et al., 2005 and 2007; Pilet et al., 2008 and 2011; Herzberg, 2011; Niu et al., 2012; Trela et al., 2015 and references therein). These enriched mantle sources are believed to have been developed by injection of melts derived from oceanic crust 
or sediment through subduction zone processes or by infiltration of low degree partial melts or fluids from lower mantle.

This contribution is oriented to summarize (1) nature of Proterozoic mafic magmatism in the Indian shield and (2) prominent petrological features of this magmatism, and then try to account for these features in the context of our present understanding of mantle evolution. Some comparisons will also be drawn with Phanerozoic continental flood basalt provinces, where relevant in view of some similarities between these two magmatic events. New precise U-Pb ages have started appearing from the Indian shield, as summarized in the following section, to indicate the occurrence of mafic magmas at different intervals during the Proterozoic; they provide a useful window to monitor mantle evolution, particularly the sub-continental lithosphere, which appears to be the dominant source for enriched compositions of the most mafic igneous occurrences. Thermal energy needed for these igneous events may lie within mantle plumes. The conclusions reached in this study may contribute to the thermal evolution and mantle plume debate (e.g. Campbell, 2005; Davies, 2005; Foulger, 2005; Foulger et al., 2005; Niu, 2005; Campbell and Davies, 2006) although the debate cannot be resolved using the geochemistry alone.

\section{Geological Features of Mafic Igneous Activity}

The Indian shield comprises vast terrains of Archaean cratons,

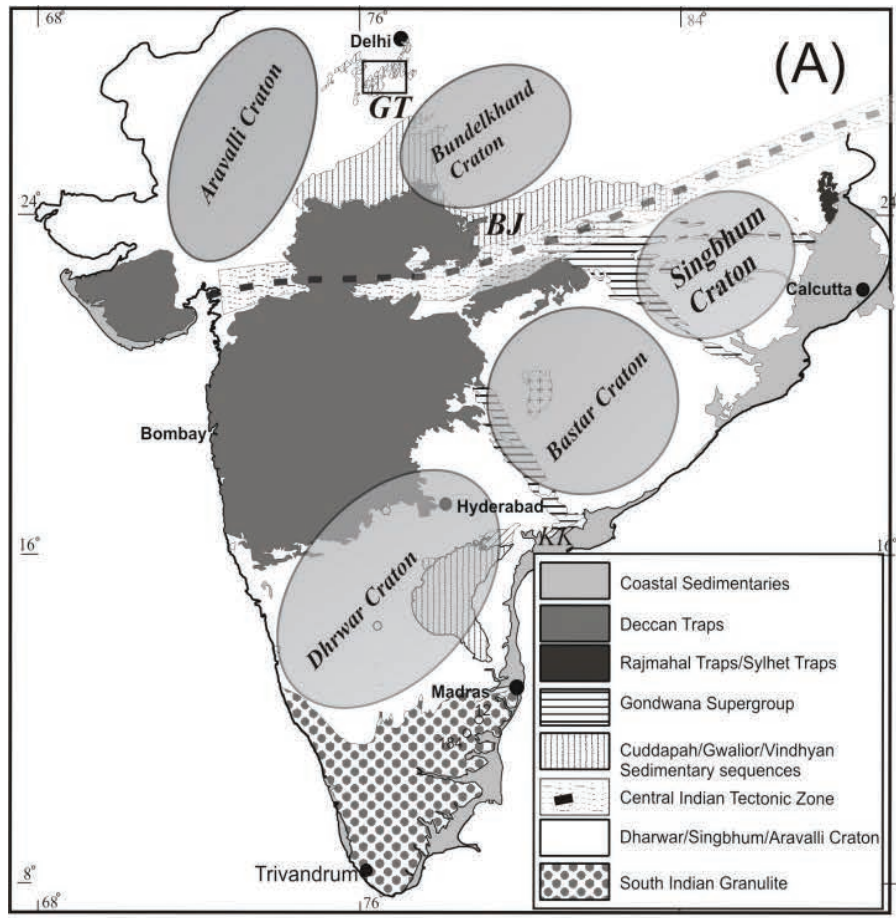

Proterozoic basins and mobile belts. The Dharwar, Bastar, Singhbhum, Bundelkhand and Aravalli cratons in India are among the oldest cratons of the world. The Cuddapah, Gwalior, Bijawar and Vindhyan are the prominent Palaeoproterozoic sedimentary basins formed on the cratonic margins. Granulite terrain in South India and the Eastern Ghats Belt towards the east coast constitute the prominent Precambrian mobile belts.

The Proterozoic magmatism has significant presence in all the cratons, sedimentary basins and mobile belts. It occurs more frequently in the form of mafic dykes as has been observed in many other cratons of the world (Ernst, 2014), but are never seen extending into the sedimentary basins. The dyke intrusions in the Dharwar craton and adjoining granulite terrain have been the subject of extensive multidisciplinary studies. Profuse occurrence of these dykes is seen on western margin of the Cuddapah Basin and is grouped into three/ four strike trends. These dykes appear to extend all along the Dharwar craton up to the west coast, but are distributed as individual clusters in different areas all across the craton and also extend in south into the northern parts of adjoining granulite region of south India (Fig. 1). Mafic dyke intrusions in the Bundelkhand and Bastar cratons appear to be more continuous without much intermittent discontinuity. Mafic dykes represent the main Proterozoic mafic igneous activity in Singhbhum and Aravalli cratons too. Palaeoproterozoic mafic dykes and lava flows are known from Eastern Ghats Belt and adjoining regions (Fig. 1). Mafic magmatism is known from the Dongargarh belt, the Bastar craton and as Dalma traps from the Singhbhum craton. The former is unusually crustal-contaminated

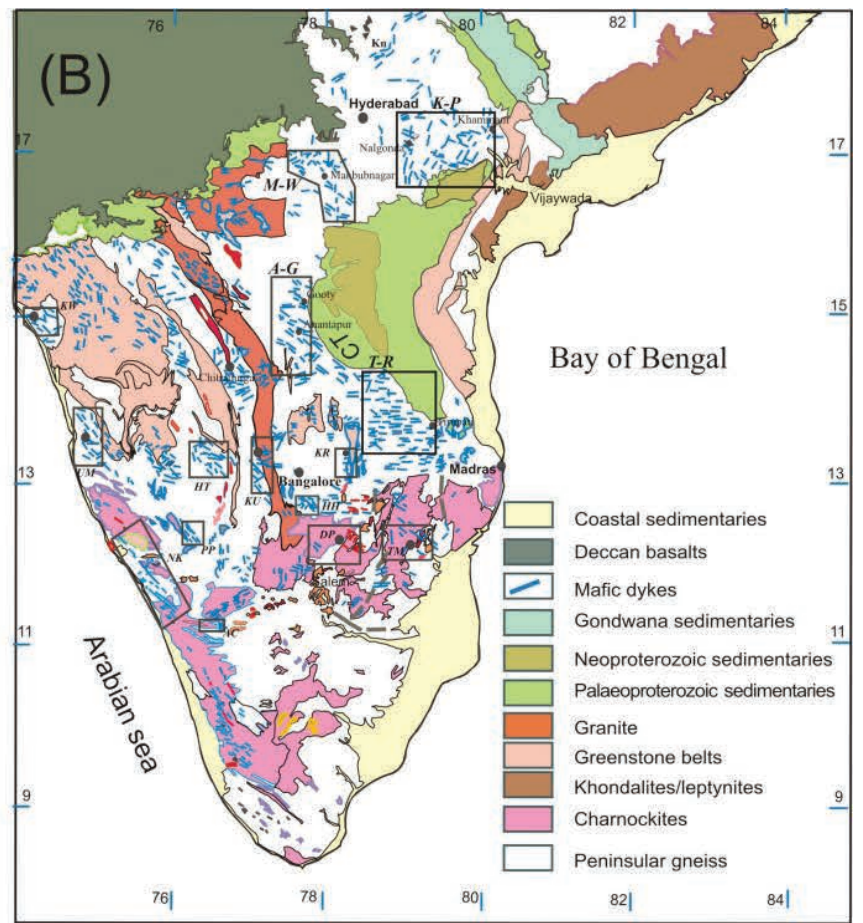

Figure 1: (a) Map illustrating broad geological sketch of the Indian shield with locations of the Palaeoproterozoic mafic igneous emplacements. The mafic igneous activity is manifested as dyke intrusions within the Dharwar, Bundelkhand, Bastar and Singhbhum cratons. Locations of the Gwalior, Bijawar and Kondapalli-Kandra emplacements are marked as GW, BJ and KK respectively; (b) more detailed geological sketch of the south India showing locations of studied dyke intrusions as rectangles Khammam-Peddavur (KP), Mahabubnagar-Wanaparti (MW), Anantapur-Gooty (AG) and Tirupati-Raychoti (TR) are around the Cuddapah Basin; Kolar (KR), Harohalli (HH), Kunigal (KU) are in the Eastern Dharwar craton away from the Cuddapah Basin; Udupi-Mangalore (UM), Piriyapatna (PP) and Karwar (KW) are in the Western Dharwar craton; Tiruvannamalai (TM), Dharmapuri (DP), Agali-Coimbatore (AC) and north Kerala (NK) are in the Southern Granulite Terrain. Location of the Cuddapah traps/intrusives is demarcated as CT. 
(Sensarma et al., 2002) and therefore do not permit source characterization. In case of the Dalma volcanics, precise ages or palaeomagnetic constraints are not available and are considered to show oceanic signatures (Yellur, 1977; Roy et al., 2002). Thus these two occurrences are excluded for the present discussion.

The mafic igneous activity is manifested in the form of dykes probably because fractures can propagate rapidly and opening fractures can be quickly filled with fluid magma. The abundant dyke population clearly reflects significant extension and the cause of the extension may be related to mantle processes, even though the tectonic environment differs. Now we know that dyke intrusions can propagate laterally for hundreds of kilometers, and conceptually it is difficult to imagine why magma should penetrate laterally for such huge distances (Tarney, 1992). Consequently, the clusters over a large area in the Dharwar craton may have genetic linkages and the volume of magma involved in each dyke event must be fairly large. For example, the volume of magma involved in the 1250 Ma old Mackenzie Swarm centered around Muskox intrusion is estimated at $90000 \mathrm{~km}^{3}$ (Fahrig, 1987). Such volumes are comparable with some Phanerozoic Large Igneous Provinces (LIPs) represented by continental flood basalt provinces. However, the Phanerozoic flood basalt eruptions, in contrast to Proterozoic mafic igneous activity, occur as large surface eruptions with relatively limited number of genetically linked dyke intrusions. Erosion may be argued as one of the causes for the lack of surface eruptions corresponding to Proterozoic dykes, however, the explanation is not conclusive as the volcanic units of Archaean age and some volcanic units of Proterozoic age are well preserved. In this context, the trap rocks in the Cuddapah basin, south India and the Gwalior and Bijawar volcanics in the sedimentary basins in Central India stand as best Indian examples.

The mafic igneous units in the form of surface eruptions are very small in volume and are always present within the lower stratigraphic sections of the Palaeoproterozoic basins. In south India, these rocks are exposed along the western margin in the lower Cuddapah succession (Fig. 1), unconformably overlying the granite-gneiss complex of the Eastern Dharwar craton. These igneous units are variably described as basaltic flows, mafic/ultramafic sills and ash fall tuffs (Srikantia, 1984; Nagaraja Rao et al., 1987; Anand et al., 2003). The Gwalior and Bijawar traps occur in the Palaeoproterozoic Gwalior and Bijawar basins respectively in central India (Fig. 1). The Gwalior traps occur as basaltic lavas underlying the upper Vindhyan Supergroup (Crawford and Compton, 1970) or as sills (Samom et al., 2017). The Bijawar mafic igneous rocks comprise both volcanic flows and gabbro units. The Kondapalli-Kandra Palaeoproterozoic mafic rocks occur as dykes, sills and flows within the Nellore Schist Belt-Eastern Ghat Belt tectonic milieu and represent plate-margin igneous activity (Fig. 1).

A few observations are worth making here. In spite of propagation to such large lateral extent, it is puzzling that these dyke intrusions like their counterparts in the world do not have the silicic compositions. Similarly, the dykes although were emplaced into the high-grade granulite and amphibolite facies gneisses, the country rock never shows signs of melting. No central igneous complexes (magma chambers) feeding the Palaeoproterozoic dyke intrusions are noticed. Only on the southwestern segment of the Cuddapah Basin, presence of a high-density lopolithic magmatic body that may have fed the dyke intrusions was postulated (Krishna Brahmam and Dutt, 1992; Rambabu, 1993; Mishra and Tiwari, 1995; Anand et al., 2003; Radhakrishna et al., 2007).

\section{Chronology, Palaeomagnetism and Periodicity}

Precise dating of mafic igneous units has been a difficult task for long time. The initial K-Ar and the Rb-Sr whole rock isochron methods yielded a spectrum of ages covering almost the whole of Proterozoic Eon. However, Halls (1987) compilation on Proterozoic mafic magmatism shows discrete events separated by periods of inactivity. Advances of U-Pb zircon and baddeleyite dates (LeCheminant and Heaman, 1989) of mafic igneous units yielded ages with much higher precision and improved our understanding of temporal controls on mafic magmatic activity. Palaeomagnetic characteristic magnetization results provide an added advantage to identify discrete igneous events when integrated with high precision $\mathrm{U}-\mathrm{Pb}$ geochronology. There have been reports of a few $\mathrm{U}-\mathrm{Pb}$ baddeleyite Palaeoproterozoic ages on igneous units from the Dharwar craton of the Indian shield (Halls et al., 2007; French et al., 2008; French and Heaman, 2010; Kumar et al., 2012 and 2015) and Sm-Nd whole rock-mineral isochron ages (Zachariah et al.,1995; Dash et al., 2013). Similarly two U-Pb baddeleyite Palaeoproterozoic ages are available from the igneous units of the Bastar craton (French et al., 2008; Gregory et al., 2018). A U-Pb zircon Palaeoproterozoic date is reported from mafic dyke intrusion of the Bundelkhand craton (Pradhan et al., 2012) and Southern Granulite terrain (Pivarunas et al., 2018). Precise U-Pb age of $1.85 \mathrm{Ga}$ was obtained for a sheeted dyke from the Kandra ophiolite complex in SE India (Vijaya Kumar et al., 2010). Although there are some re-equilibration problems with $\mathrm{U}-\mathrm{Pb}$ zircon or rutile dates, judicious use of these dates may identify discrete events. Simultaneously, large number of palaeomagnetic results was also obtained recently from Palaeoproterozoic mafic dyke intrusions in these cratons and adjacent granulite region (Radhakrishna and Mathew, 1996; Radhakrishna et al., 2003; Halls et al., 2007; Meert et al., 2011; Pradhan et al., 2012; Radhakrishna et al., 2013a; Radhakrishna et al., 2013b; Pivarunas et al., 2018). Integration of the $\mathrm{U}-\mathrm{Pb}$ ages with the palaeomagnetic results identified at least four discrete Palaeoproterozoic igneous events at 2.36-2.37 Ga, 2.1-2.2 Ga, 2.1-2.0 Ga 1.99-1.89 Ga and probably two other events at about 2.4 Ga and $1.8 \mathrm{Ga}$. Although the igneous activity in the Indian shield comprises distinct phases of igneous emplacements, the proportion of mafic magmatic units in each phase is not known. Recent focus of $\mathrm{U}-\mathrm{Pb}$ baddeleyite dating in Singhbhum craton have yielded ages close to the 2.2-2.1 Ga and 1.8 Ga groups (Shankar et al., 2014; Srivastava et al., 2019) and also unraveled presence of older Neoarchaean (2.75$2.80 \mathrm{Ga}$ ) mafic intrusive pulses (Kumar et al., 2017) that are outside the scope of this work.

There are reports of $\mathrm{U}-\mathrm{Pb}$ Neoproterozoic zircon ages from one mafic dyke in each of the two Cratons (1025.6 \pm 3.8 Ma on the western margin of Cuddapah Basin in the Dharwar craton; Pradhan et al., 2010; $1113 \pm 7.4$ Ma on one mafic dyke of the Bundelkhand craton; Pradhan et al., 2012). However, sufficient palaeomagnetic directions that characterize this Neoproterozoic igneous activity are not available at present.

\section{Geochemistry and Petrological Features}

A large body of major and trace element geochemical data has accumulated for Proterozoic igneous suites across the cratons in the Indian shield see Table 1. The igneous units in south India are also 


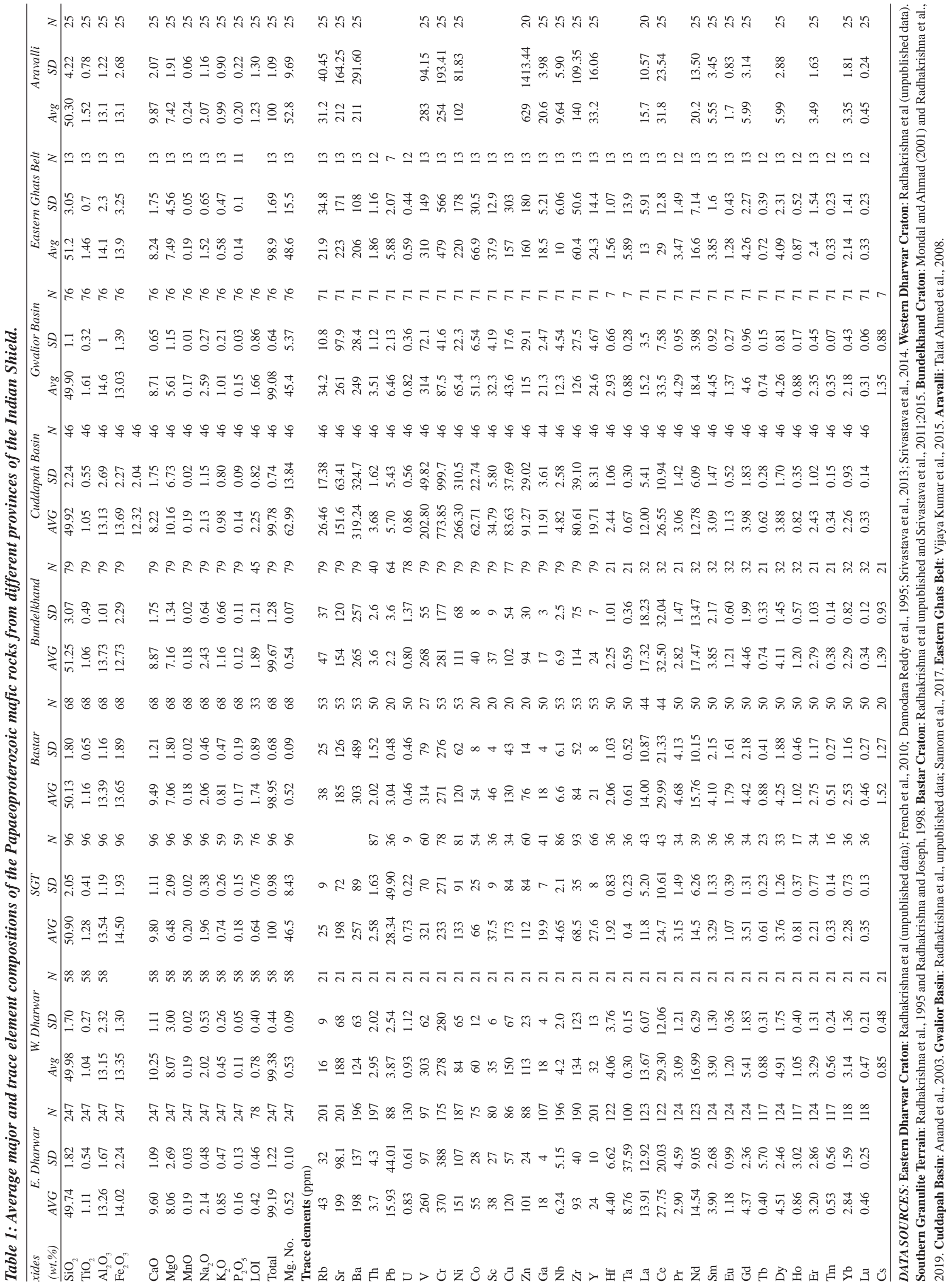


fairly characterized chronologically and palaeomagnetically (Zachariah et al.,1995; Radhakrishna and Mathew, 1996; Dash et al., 2013; Halls et al., 2007; French et al., 2008; French and Heaman, 2010; Kumar et al., 2012; Radhakrishna et al., 2003, 2013a and 2013b; Gregory et al., 2018). Trace element (Radhakrishna et al., 1995; Radhakrishna and Mathew, 1998; Anand et al., 2003; authors unpublished data and as detailed in figure 2 caption), and Sr-Nd and/or O-isotopic compositions are known from some mafic intrusions (Radhakrishna et al., 1995; Radhakrishna and Mathew, 1998; Pandey et al., 1997) and for the Cuddapah trap rocks (Anand et al., 2003).

The clusters of igneous units, represented either in the form of dykes or volcanic eruptions/sills in all cratons/basins, have restricted mineralogical and geochemical compositional ranges. Augite, plagioclase and titanomagnetite \pm minor hypersthene constitute the mineralogy of the Palaeoproterozoic mafic magmas. Most of the mafic rocks are oversaturated quartz tholeiites, but range to olivine tholeiites. In the total alkali-silica diagram of Le Maitre (2002; Fig. 2), these igneous units are sub-alkalic tholeiitic basalts and rarely range into basaltic andesites. Co-magmatic suites of andesitic or dacitic character are virtually absent. They show a clear Fe-enrichment trend, and this is matched by a wide range of REE and trace element abundances. This trend appears to be common for all the Palaeoproterozoic igneous rocks worldwide. Conversely, alkaline magma types are not present in Early Proterozoic igneous suites, as observed on almost every craton across the globe (e.g. North America, Condie et al., 1987; Greenland, Nielsen, 1987; Antarctica, Sheraton et al., 1990; see other compilations in Halls and Fahrig, 1987). Magmas of true alkaline nature appear to become much more significant in the later Proterozoic and particularly after $1.5 \mathrm{Ga}$ (Leelanandam et al., 2006). The trace element geochemistry of the Palaeoproterozoic igneous suites is summarized in the chondritenormalized REE plots (Fig. 3) and mantle-normalized multi-elemental plots (Fig. 4). The variations within individual suite of rocks are controlled by fractional crystallization, a feature marked by lowering of Mg number with increasing REE abundances. The shapes of the patterns show moderate enrichment in the LREE and lithophile elements, distinct negative $\mathrm{Nb}$ (and $\mathrm{Ta}$ ) anomalies and smaller negative $\mathrm{Sr}$ anomalies; some of the samples have small negative $\mathrm{Ti}$ anomalies.

The isotope data of the samples exhibit a moderate range in ${ }^{87} \mathrm{Sr} /$ ${ }^{86} \mathrm{Sr}_{\mathrm{i}}$ ratios (0.70322- 0.7063 for mafic intrusions in granulite region; 0.7052-0.7081 for Traps/intrusive basalts in Cuddapah Basin). Their ${ }^{143} \mathrm{Nd} /{ }^{144} \mathrm{Nd}_{\mathrm{i}}$ ratios vary between 0.5097 and $0.5102 ; \varepsilon \mathrm{Nd}$ values correspondingly range from +1 to -10 . Sr and $\mathrm{Nd}$ isotopic values of similar range are also reported from 1.88 Ga BD2 dykes in Bastar craton (Srivastava et al., 2009) and Bijawar igneous units (Pandey et al., 2012). In a Sr-Nd isotope plot (figure not shown), the Proterozoic mafic samples strikingly differ from the mantle components defined by Hart and Zindler (1989). The oxygen isotope data provide an important insight to the petrogenetic problem. Available whole rock $\delta^{18} \mathrm{O}$ values for the Indian Proterozoic igneous intrusives (Fig. 5) are rather uniform and mostly ranging between +5 and $+6 \%$, relative to standard mean ocean water (SMOW). By comparison, the mean $\delta^{18} \mathrm{O}$ value for typical MORB glasses is $+5.5 \pm 0.2$ \% (e.g. Eiler 2001; Cooper et al., 2004). For fresh whole-rock samples of ocean island basalt, values of $\delta^{18} \mathrm{O}$ generally are $<+5.8 \%$ (Kyser et al., 1990; Eiler, 2001).

Most of the whole population of Palaeoproterozoic igneous rocks from India have Mg numbers $<0.60$ and correspondingly MgO values are $<9.0 \mathrm{wt} \%$ (down to $4 \mathrm{wt} . \%$ ) with $\mathrm{Cr}$ and $\mathrm{Ni}$ values as low as $<200 \mathrm{ppm}$ and $<100 \mathrm{ppm}$ respectively indicating variable degrees of fractionation. Only some mafic to ultramafic sill samples in the Cuddapah Basin have their MgO contents ranging up to $28 \mathrm{wt} \%$ due to olivine accumulation. A plot between $\mathrm{Mg \#}$ and (La/Lu) $)_{\mathrm{N}}$ (Fig. 6) clearly indicates the dominant role played by fractional crystallization in the compositional variation of the Palaeoproterozoic magmas in the Indian shield. Only a few samples show effects of assimilation fractionation. Vectors for partial melting, fractional crystallization and assimilation fractional crystallization are shown in the Figure 6. It seems Proterozoic magmas from the Bastar and Bundelkhand cratons are formed by higher degrees melting compared to those from Gwalior and Cuddapah basins as illustrated by lower $(\mathrm{La} / \mathrm{Lu})_{\mathrm{N}}$ ratios at similar Mg\#s. Alternatively, the mantle sources for Proterozoic magmas from the Bastar and Bundelkhand cratons could be more enriched compared to those for Gwalior and Cuddapah basins. The fractional crystallization involved olivine + clinopyroxene \pm plagioclase \pm orthopyroxene. It is interesting that the fractionation trends are Fe-rich tholeiitic and calc-alkaline trends are virtually absent. This appears true for the early Proterozoic rocks worldwide. Even the Scourie dykes (Weaver and Tarney, 1981) with variable amounts of primary hornblende ( \pm biotite) that reflect high $\mathrm{pH}_{2} \mathrm{O}$ conditions during crystallization never follow calc-alkaline fractionation trend with the implication that high $\mathrm{pH}_{2} \mathrm{O}$ is not the only factor determining fractionation trends; these conditions are suggested to have been inherited at source region. The mantle sources 

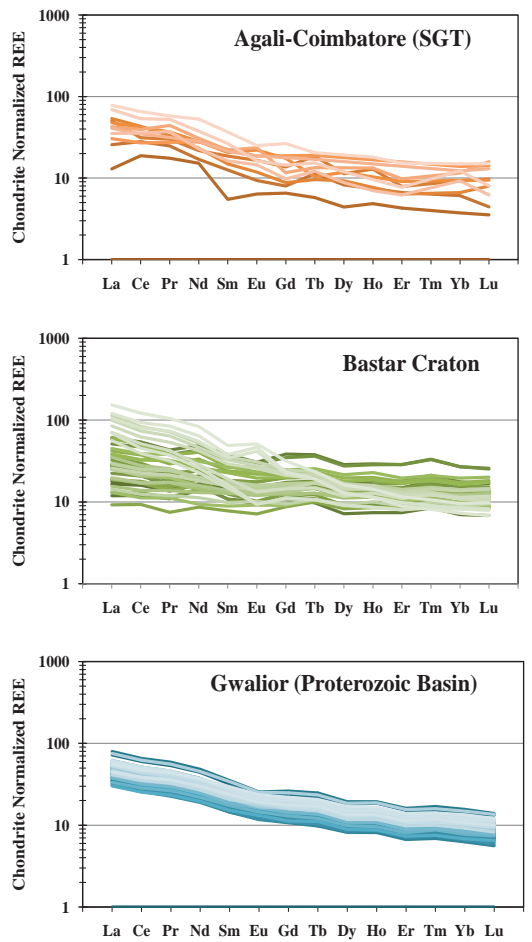

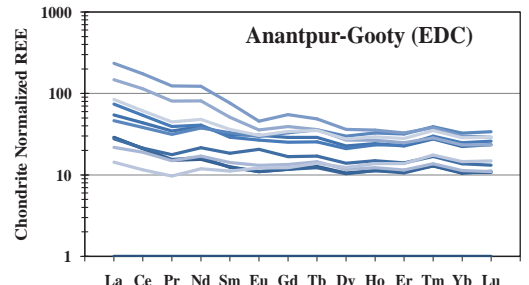

La Ce Pr Nd Sm Eu Gd Tb Dy Ho Er Tm Yb Lu
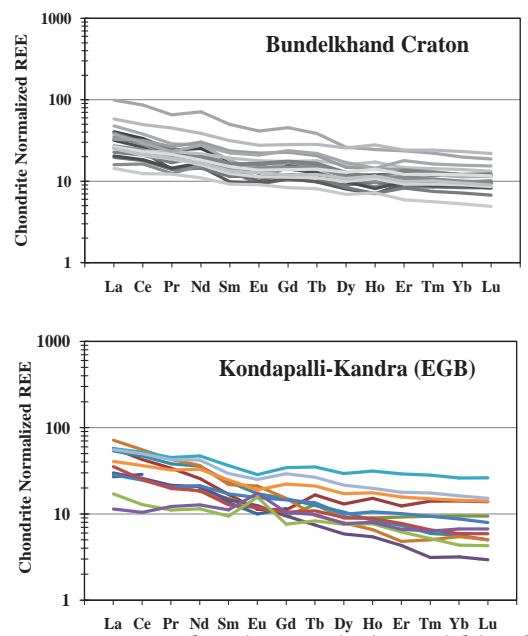
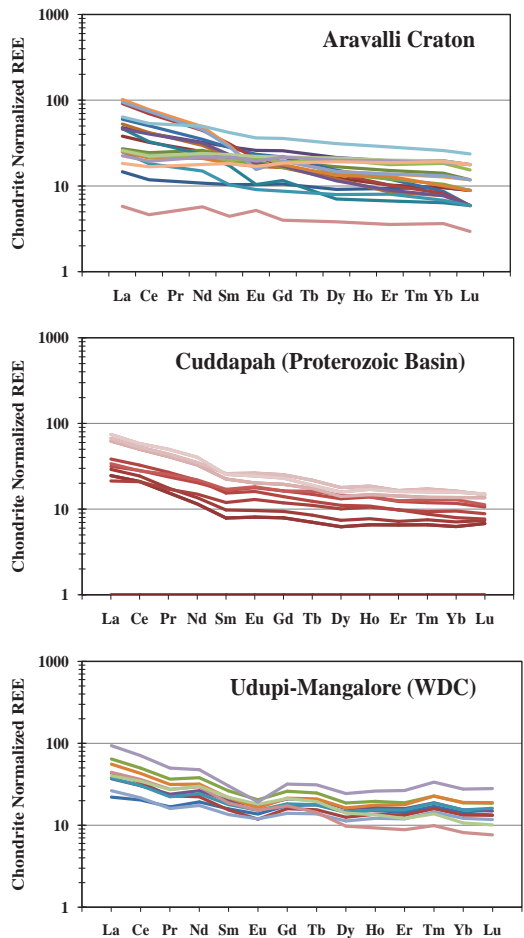

Figure 3. Chondrite-normalized rare earth element patterns showing variation within the Palaeoproterozoic mafic igneous occurrences from cratons and sedimentary Basins of the Indian shield. Chondrite values are after Sun and McDonough (1989). For discussion see the text. Legend Abbreviations: SGT = Southern Granulite Terrain; EGB = Eastern Ghats Belt; EDC = Eastern Dharwar Craton; WDC = Western Dharwar Craton.

Region-wise details are as follows: Agali-Coimbatore mafic dykes (South Indian Granulite Terrain); Anantapur-Gooty mafic dykes (Eastern Dharwar craton on the margins of Cuddapah Basin); Aravalli, Bundelkhand and Bastar cratons in Northern and Central India; Cuddapah and Gwalior are traps/sills within the Cuddapah Basin in south India and Gwalior Basin in northern India; Kondapalli-Kandra mafic rocks are from the Eastern Ghats Belt; Udupi-Mangalore mafic dykes (Western Dharwar craton).
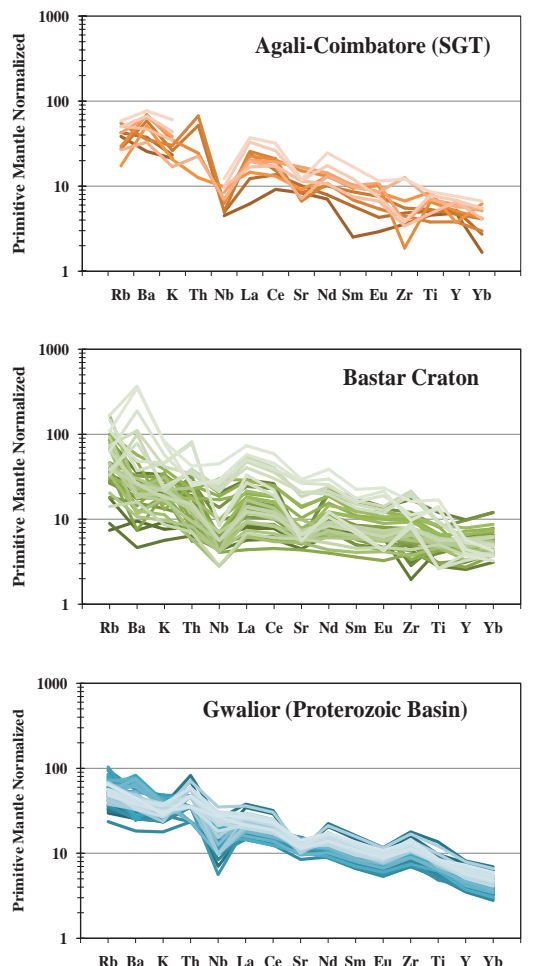

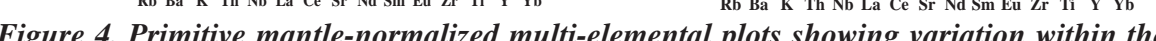

in figure 3. For discussion see the text.
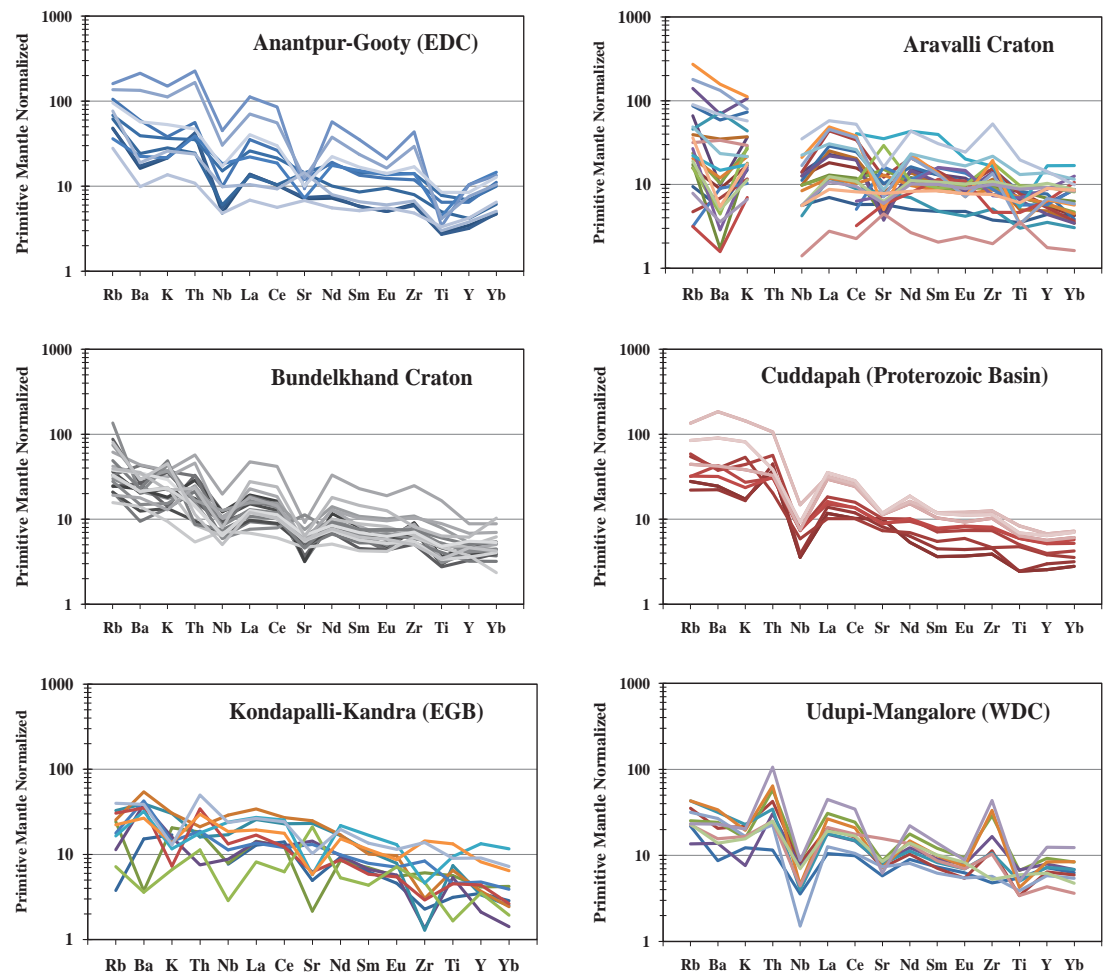


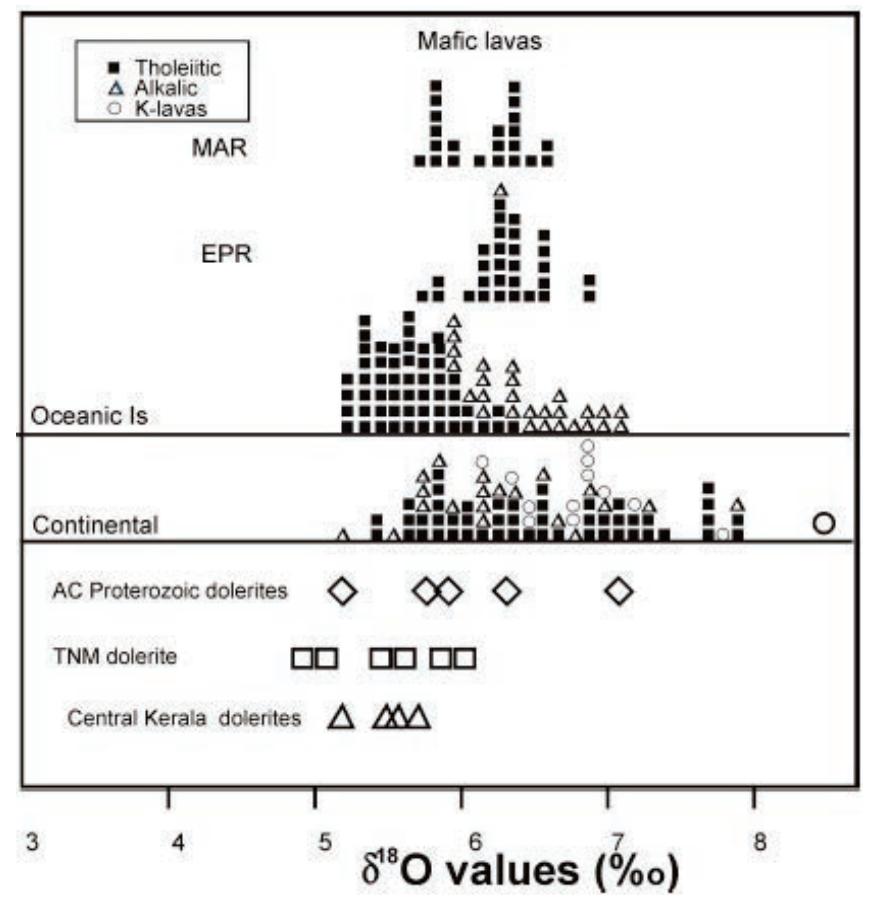

Figure 5. Whole-rock $\delta^{18} \mathrm{O}$ values from mafic igneous intrusive samples of south India compared with the values of Continental and Oceanic mafic lavas (Kyser, 1990). Values from late Cretaceous (65-70 Ma) dolerites of Central Kerala are also plotted for comparison. Figure modified after Radhakrishna et al. (2004).

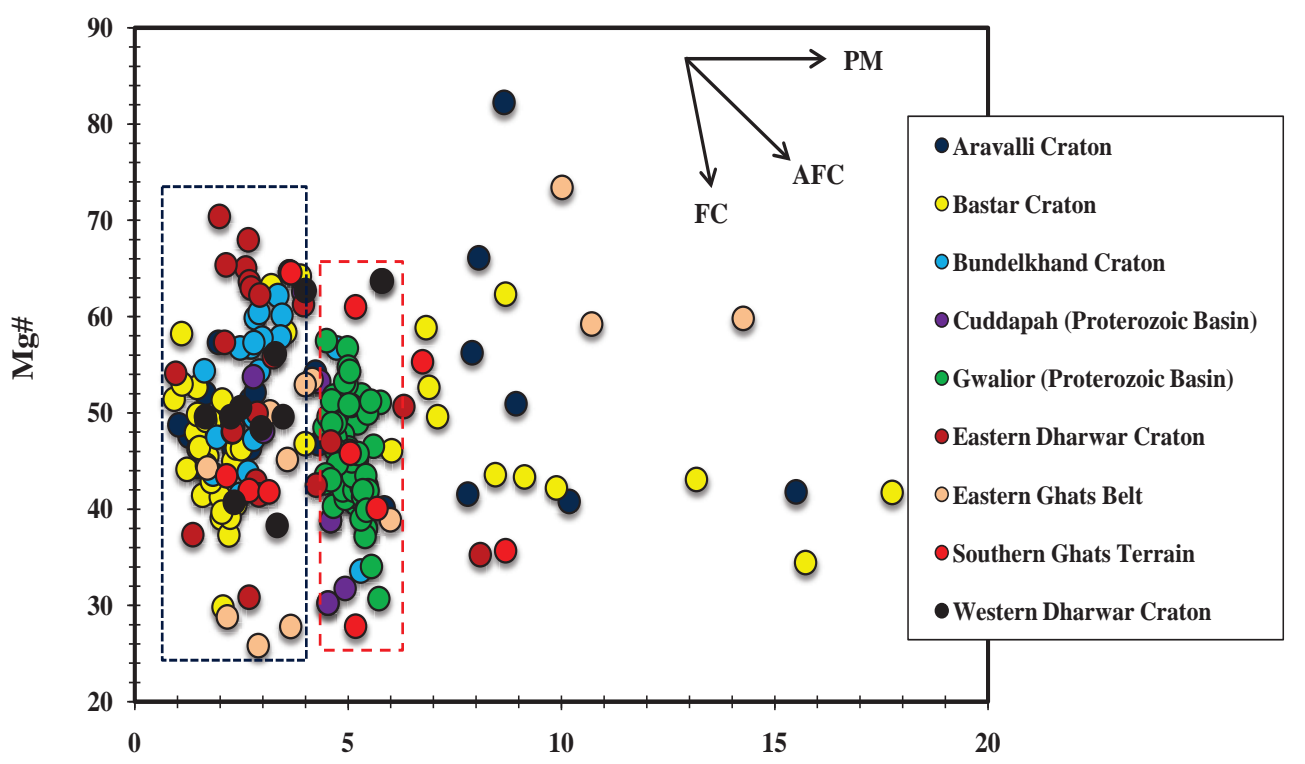

$(\mathrm{La} / \mathrm{Lu})_{\mathrm{N}}$

Figure 6: $\mathrm{Mg} \#$ versus $(\mathrm{La} / \mathrm{Lu})_{N}$ plot for the Palaeoproterozoic mafic igneous rocks from the Indian shield. Geochemical variation in the Palaeoproterozoic magmas in the Indian shield can be explained by fractional crystallization wherein for a large decrease in $\mathrm{Mg \# s}$ there is only a little increase in (La/ $\mathrm{Lu})_{N}$ ratios. Only few samples show possible effects of assimilation fractional crystallization. It seems Proterozoic magmas from Bastar and Bundelkhand cratons are formed by higher degrees melting compared to those from Gwalior and Cuddapah basins as illustrated by lower $(\mathrm{La} / \mathrm{Lu})_{N}$ ratios at similar Mg\#s (shown in dotted squares). Vectors for fractional crystallization (F), assimilation fractional crystallization (AFC) and partial melting (PM) are shown. Legend Abbreviations as in figure 3 beneath the old Archaean cratons seem to be quite reduced (Daniels and Gurney, 1991).

The compositions (LREE and LIL elemental enrichment and negative $\mathrm{Nb}$ anomalies) of the Proterozoic continental mafic igneous rocks are argued to be the result of massive crustal contamination of magma while some others prefer, in sharp contrast, contamination of the mantle source itself. Incompatible element ratios and isotopic ratios are used to negate significant crustal contamination of the Proterozoic mafic dyke intrusions in south India (Radhakrishna et al., 1995; Radhakrishna and Mathew, 1998) and in Bundelkhand craton (Radhakrishna et al., 2019). Furthermore, there are no field evidences of crustal melting associated with any of the Proterozoic gneous occurrences in India. It is demonstrated in many Proterozoic igneous units that crustal contamination has no significant role in (for example, Scourie dykes: Weaver and Tarney, 1981 Available $\delta^{18} \mathrm{O}$ values of the Indian Palaeoproterozoic igneous units are not in conformity with any significant crustal contamination. A comparison between $1 / \mathrm{Nd}$ and ${ }^{143} \mathrm{Nd} /{ }^{144} \mathrm{Nd}$ (Fig. 7) of all available ata from different igneous units in India is inconsistent with a simple mixing model between crust and mantle-derived melts although it is impossible to rule out non-systematic mixing with the present data of mantle melts with local crust in some samples of the lavas and intrusives of the Cuddapah Basin.

Majority of the Palaeo-proterozoic rocks from the Indian shield fall in the field for sub-continental lithospheric mantle derived basalts except a few samples (particularly Kondapalli-Kandra) falling within the field for sub-lithosphere mantle in the plot defined by $\mathrm{Th} / \mathrm{Yb}$ versus $\mathrm{Ta} / \mathrm{Yb}$ variation (Fig.8A; Pearce, 2003). Some samples from Bastar, Bundelkhand extend into the sublithosphere field. For comparison, Phanerozoic Deccan flood basalts are shown in the figure. The Deccan basalts are grouped into Plumederived and Lithosphere-derived based on geochemical and isotopic signatures (Vijaya Kumar et al., 2018). Majority of the Plume-derived basalts are restricted to the sublithosphere array. However, some of the plume-derived basalts plot above the field for melts derived from sublithosphere mantle sources (Fig.8A). Such a variation is interpreted in terms of overprinting on original sublithospheric mantle sources (Pearce, 2003) or crustal contamination of deeper mantle derived magmas (Arculus, 1987). The Deccan basalts with strong lithosphere component exclusively plot above the field for melts derived from the sublithospheric mantle sources (Fig. 8A). It is clear that none of the Palaeoproterozoic mafic magmas and Deccan igneous rocks illustrate true 


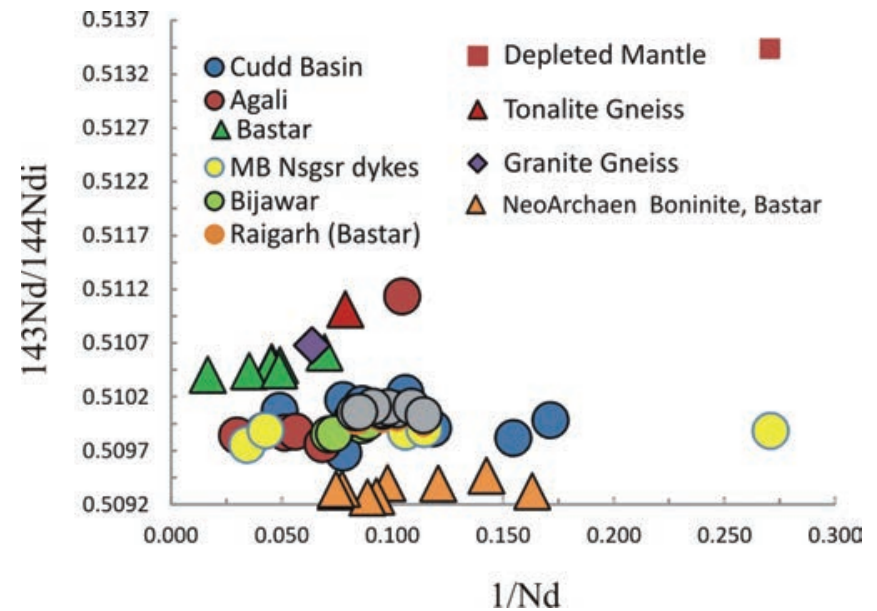

Figure 7: ${ }^{143} \mathrm{Nd} /{ }^{144} \mathrm{Nd} \mathrm{d}_{\mathrm{v}}$ versus1/Nd plot for the Palaeoproterozoic mafic magmas from the Indian shield. Samples from mafic intrusives of granulite region south of Nilgiri massif (Agali; Radhakrishna et al., 1995), mafic flows/sills in the Cuddapah Basin (Anand et al., 2003), MB Nagar mafic dykes on the margin of Cuddapah Basin (Pandey et al., 1997), Bijawar igneous rocks in Central India (Pandey et al., 2012) and Raigarh region in Bastar (Pandey et al., 2012) are plotted. Depleted mantle (DM) of Miller and $O$ 'Nions (1985) and Tonalite Gneiss and Granite Gneiss values of Peucat et al. (1989) are also plotted. These compositions differ sharply from the compositions of Neoarchaean boninite units of the Bastar region (Srivastava et al., 2009).

NMORB signatures alone (Fig. 8A). We suggest that a dominant lithosphere component for most of the mafic rocks of the Palaeoproterozoic and Phanerozoic igneous provinces of India.

Similar results are obtained based on $\mathrm{Th} / \mathrm{Nb}$ and $\mathrm{Zr} / \mathrm{Nb}$ relationship (Fig. 8B), which demonstrates that very few mafic rocks from Bastar, Bundelkhand cratons have lower $\mathrm{Th} / \mathrm{Nb}(<0.15)$ ratios geochemical characteristics similar to sub-lithospheric mantle sources (Fig. 8B). Typical depleted mantle derived NMORB-type melts are located remotely from the Palaeoproterozoic mafic magmas from the Indian shield. We suggest that mafic magmas with $\mathrm{Th} / \mathrm{Nb}$ ratios $>0.4$ (Fig. 8B) represent melts exclusively derived from or with significant contribution from sub-continental lithospheric sources. Mafic magmas with $\mathrm{Th} / \mathrm{Nb}$ ratios between 0.15 and 0.4 overlap, which we interpret in terms of lithosphere-plume interaction.

\section{Mantle Sources}

\section{Sources responsible for enriched geochemistry (subducted oceanic crust vs SCLM)}

The above arguments point out that the mantle source of the Indian Proterozoic mafic igneous units is actually enriched in incompatible elements than the primitive mantle (PM: Sun and McDonough, 1989; Lyubetskaya and Korenaga, 2007). Such enriched sources are now known in many continental basalt provinces and the ocean island basalts. However, the processes of enrichment significantly vary as reflected by abundances and ratios of incompatible elements, as well as radiogenic isotopes. The heterogeneities resulting from addition of distinctly different metasomatic agents are generally accepted due to plate and plume tectonics.
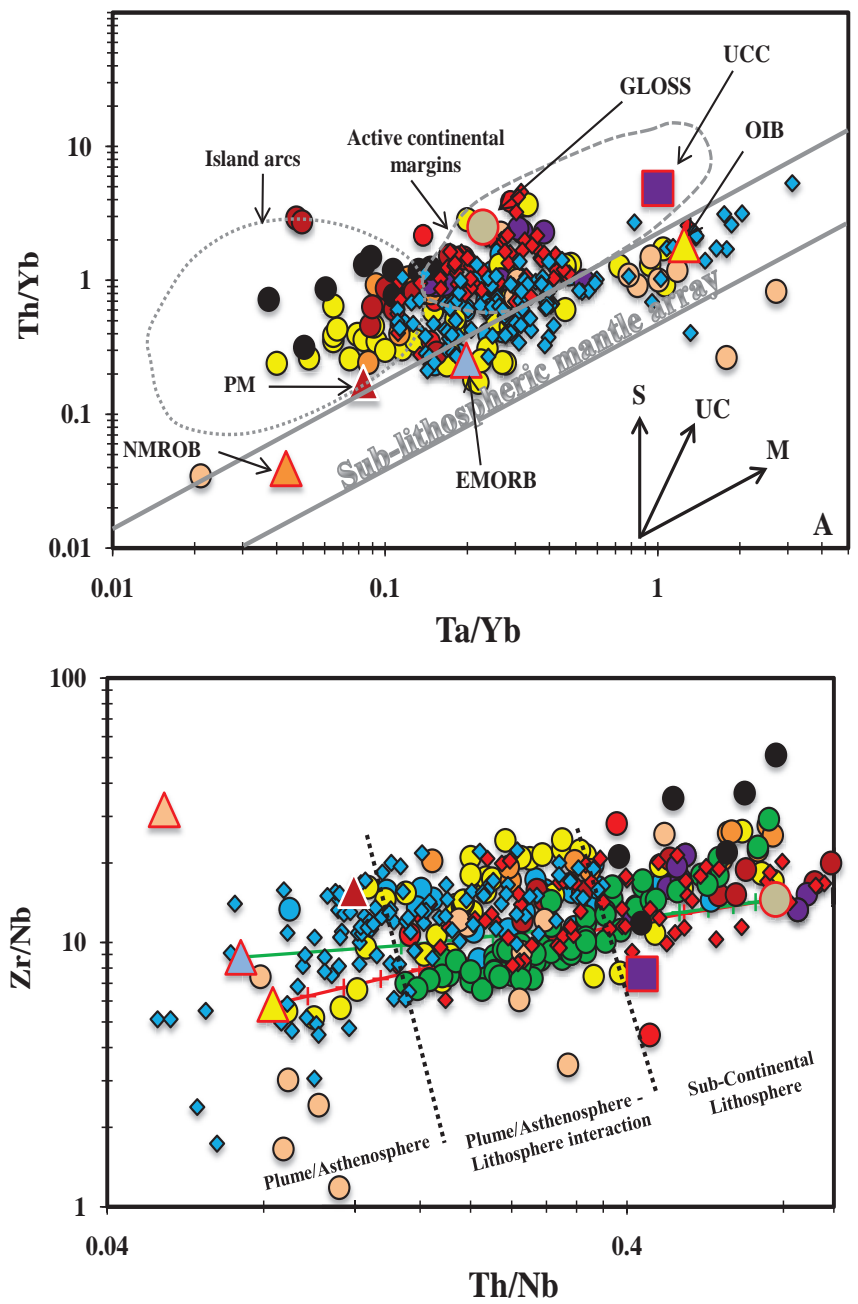

Figure 8: $\mathrm{Th} / \mathrm{Yb}$ versus $\mathrm{Ta} / \mathrm{Yb}$ (A) and $\mathrm{Zr} / \mathrm{Nb}$ versus $\mathrm{Th} / \mathrm{Nb}(\mathrm{B})$ variations in the Palaeoproterozoic mafic igneous rocks from the Indian shield (the colour and symbol codes are as given in figure 6). Plume- and Lithosphere-derived basalts from the Phanerozoic Deccan flood basalt province are shown for comparison. Fields for sub-lithospheric mantle, island arc and active continental margin are after Pearce (2003). The compositions for NMORB (normal mid-ocean ridge basalt), EMORB (enriched mid-ocean ridge basalt, PM (primitive mantle) and OIB (ocean island basalt) are after Sun and McDonough (1989); composition of UCC (upper continental crust) is after Rudnick and Gao (2003). Vectors for addition of subducting component (S), upper crustal contamination (UC) and partial melting (M) are shown.

Three major hypotheses were proposed for the enriched component(s) in the source in terms of incompatible trace elements (see for details Niu et al., 2012):

(1) The hypothesis of recycled oceanic crust wherein the subducted ocean crust returns to upper mantle via core-mantle boundary as proposed by Hofmann and White (1982). However, the incompatible trace element chemistry is not in conformity with the proposed recycled oceanic crust contribution. Relatively more incompatible trace element patterns as in the early Proterozoic magmas cannot be reproduced from the recycled oceanic crust either theoretically or experimentally (Hirschmann et al., 2003; Kogiso et al., 2003; Dasgupta et al., 2007; Pilet et al., 2008). The model 
subsequently underwent some revision. According to the revised model, pyroxenite sources develop by melt-rock reaction (reaction of the eclogite-derived melts with peridotite; Sobolev et al., 2005 and 2007) or solid state diffusion reaction between the eclogite (recycled oceanic crust) and harzburgite (depleted mantle) (Herzberg, 2011). These models developed by using the geochemical database of Hawaiian volcanism. Sobolev et al. (2007) very elegantly reinforced the idea to quantify the recycled ocean crust and pyroxenite content under different continental/oceanic basalt regions of different lithosphere thicknesses. For example, 10-20\% recycled oceanic crust in the sources for the MORB, up to $60 \%$ for the Hawaii OIB and $100 \%$ for the Siberian basalts. However, both the recycled oceanic crust (represented by eclogite) and the depleted mantle (represented by harzburgite) are depleted in incompatible trace elements and cannot produce enriched compositions of the Indian Palaeoproterozoic igneous rocks or other similar Phanerozoic basalt eruptions. For this reason and other reasons explained by Niu et al (2012), there are experimental and physical difficulties to support the reactions proposed in these models.

(2) Some authors have suggested that subducted terrigenous sediments (upper continental crust derived material) may be responsible for enriched signatures of mantle sources in terms of both incompatible trace elements and isotopes (e.g., Chauvel et al., 1992; White and Duncan, 1996; Hofmann, 1997; Jackson et al., 2007). In light of plate tectonics and mantle circulation models and high P experimental studies that show enriched incompatible trace element signature of sources can be attributed to recycled K-hollandite-bearing continental sediments to Transition Zone (App et al., 2008). However, subducted terrigenous sediment signatures may have been diluted in the mantle source regions and continental crust-like signatures may have been largely "smoothed out”. The Palaeoproterozoic igneous units also have subtle $\mathrm{Sr}$ depletions (Figure 4) in contrast to its enrichment in the subducted sediments (Figure 4 of Niu et al., 2012). Hence, it may be difficult to conceive subducted sediment to be the major source material for mantle metasomatism and the possibility requires further investigation.

(3) It has been recognized that mantle sources of the intra-plate continental magmatism, such as the Palaeoproterozoic igneous rocks in the Indian shield, are enriched in incompatible elements relative to the PM, e.g., $[\mathrm{La} / \mathrm{Sm}]_{\mathrm{EM}}>[\mathrm{La} / \mathrm{Sm}]_{\mathrm{PM}}$ (e.g., Sun and McDonough, 1989; McKenzie and O’Nions, 1995; Niu et al., 2002; Niu and O’Hara, 2003; Prytulak and Elliott, 2007; Humphreys and Niu, 2009). Sub-continental lithospheric mantle (SCLM) is postulated as a potential enriched source for many continental basalts (McKenzie and O’Nions, 1995). The geochemically enriched component in the SCLM must be of metasomatic origin as evidenced by the presence of hydrous minerals (e.g., amphibole, phlogopite) and vein lithologies (e.g., garnet pyroxenite, pyroxenite and hornblendite) and the idea gained wider acceptance based on mantle xenolith data (Frey and Green, 1974; Frey et al., 1978; Menzies and Murthy, 1980; Menzies, 1983; Menzies and Hawkesworth, 1987; O’Reilly and Griffin, 1988; Takazawa et al., 2000; Agashev et al., 2013; Hughes et al., 2014; Kukuª et al., 2015; Ionov et al., 2015; Puziewicz et al. 2015 and many others) and massif peridotites (Frey et al., 1985; Pilet et al., 2005). Although, the involvement of metasomatized SCLM is accepted, the mechanism of metasomatism in the SCLM that is, how the metasomatized materials enter source regions is not clearly known. However, the mechanism is suggested to be conceptually similar to that in the growing oceanic lithosphere (Niu et al., 1999, 2002; Niu and O’Hara, 2003, Niu, 2009; Humphreys and Niu, 2009)

\section{Mechanism of SCLM Development}

To begin with, the primitive mantle or a depleted mantle (as a result of previous melt removal) may be regarded as pre-metasomatic mantle sources; their metasomatism has been ascribed to infiltration by a low- $F$ melts that are enriched in volatiles (e.g., $\mathrm{H}_{2} \mathrm{O}$ and $\mathrm{CO}_{2}$ ) and incompatible elements. The experimental works by White and Wyllie (1992) and Baker and Wyllie (1992) stressed the importance of incipient partial melting in the presence of both $\mathrm{H}_{2} \mathrm{O}$ and $\mathrm{CO}_{2}$ in generating the metasomatic agents which can modify both oceanic and continental lithospheres. Some investigators have reiterated the original idea of Wyllie proposal that the Low Velocity Zone (LVZ) may be entirely or at least largely caused by $\mathrm{CO}_{2}$-generated incipient melts (e.g., Yaxley et al., 1998; Presnall and Gudfinnsson, 2005, 2008; Dasgupta et al., 2007). These results coupled with the observation that free volatile components available in the upper mantle must be $\mathrm{CO}_{2}$ or dominated by $\mathrm{CO}_{2}$ over $\mathrm{H}_{2} \mathrm{O}$ (Keppler et al., 2003) suggest that $\mathrm{CO}_{2}$-rich melt or carbonatite melt may be the metasomatic agent in the mantle.

In order to test the possible carbonatite melt metasomatism, the more primitive magma compositions of the Palaeoproterozoic (in order to eliminate the effects of fractional crystallization or assimilation fractional crystallization, if any) in India are compared (Fig.9) with the carbonatite melts of deep transition zone origin (Walter et al., 2008) and the compositional variants of the Indian carbonatites (Ackerman et al., 2017). The Palaeoproterozoic magmas, despite having some similarities, have significant deviations from the carbonatite melts of deep transition zone, natural carbonatites and the carbonatite melts simulated in high pressure experiments (Brey et al., 2008). These differences in the near primary melts indicate that carbonatite melts alone cannot be the metasomatic agents but low $\mathrm{H}_{2} \mathrm{O}-\mathrm{CO}_{2}$-rich fluids or silicate melts are necessary for the formation of SCLM. Thus, silicate melt compositions when plotted in Figure 9 (not shown), it is evident that enrichment through addition of these liquids would enhance the LILE, but would also produce considerably more than the observed levels of less incompatible elements (LREE, $\mathrm{Sr}, \mathrm{P}, \mathrm{Zr}$ and $\mathrm{Nb}$ ). Therefore, the observed enrichment pattern (LILE $>$ LREE $>$ HFSE) in the Palaeoproterozoic magmas suggests metasomatism by an incompatible element enriched fluid phase rather than by small degree partial melts. We note that Cawood et al (2018) recognised the role of fluids/melts for the enriched lithosphere mantle, but linked the process to subducted slabs that are refuted above.

These enriched components are believed to reside in the accessory mineral phases. Amphibole, apatite and phlogopite have an important role as accessory phases in producing LREE and LILE enriched melts. Judging from the abundances of LILE, P and LREE, apatite and phlogopite are not the enriched phases of the SCLM and amphibole seems to be more appropriate as the metasomatic phase. The higher $\mathrm{Kd}_{\text {amph-liq }}$ for Nb in mantle amphibole (Ionov and Hofmann, 1995) and the observation that amphibole can produce large negative $\mathrm{Nb}$ 
anomalies (Chazot et al., 1994) also do indicate the presence of amphibole as metasomatising mineral phase in the SCLM source under the Indian shield. Experimental results, showing that amphibole is stable up to about $75 \mathrm{~km}$ depth (Ringwood, 1975) and the observation that mantle sources of Hawaiian-type basalts may contain up to $10 \%$ amphibole (Hammond, 1986) are in agreement with the possible presence of amphibole in the source mantle.

\section{Role of SCLM (melting vs interaction with asthenosphere melts)}

At this stage, it is more relevant to assess the role of SCLM in the generation of Palaeoproterozoic magmas in the Indian shield. Gallagher and Hawkesworth (1992) argued that significant volume of melts can be produced from hydrated lithospheric mantle and the melts would have compositions controlled by amphibole. Arndt and Christensen (1992) argued that any thermal perturbation in lithospheric mantle cannot result in large melts generation, even if the lithosphere is wet; the $\mathrm{Nb}$ troughs can be related to a reaction of asthenospherederived magmas with lithosphere. The relative depletion of HFSE and the negative $\mathrm{Nb}$ anomalies in some flood basalts are suggested to have resulted by means of magma-mantle interaction (Kelemen et al., 1990). Similarly, the incompatible element enrichment with low $\mathrm{Nb}$ in the Proterozoic dykes of Sweden is ascribed to interaction of asthenosphere-derived melt-lithosphere mantle (Patchett et al., 1994). The present data on Proterozoic Indian igneous units may not suggest that they are entirely lithosphere mantle melts, but indicate possible interaction of lithosphere with plume/asthenosphere melts (see Fig. 8).

\section{Timing of SCLM development}

Having established the contribution of the SCLM in the petrogenesis of the Palaeoproterozoic magmas, the timing of its formation through metasomatism is an important petrological aspect. Its formation could be near contemporaneous with the generation of these magmas or alternatively, it might have inherited similar enriched elemental characteristics during the early stages of crustal building activity in the Indian shield. The isotopic data for one of the mafic dyke suites (Radhakrishna et al., 1995), which gave Sm-Nd whole rock "isochron" of ca. 3.0 Ga, is remarkably in

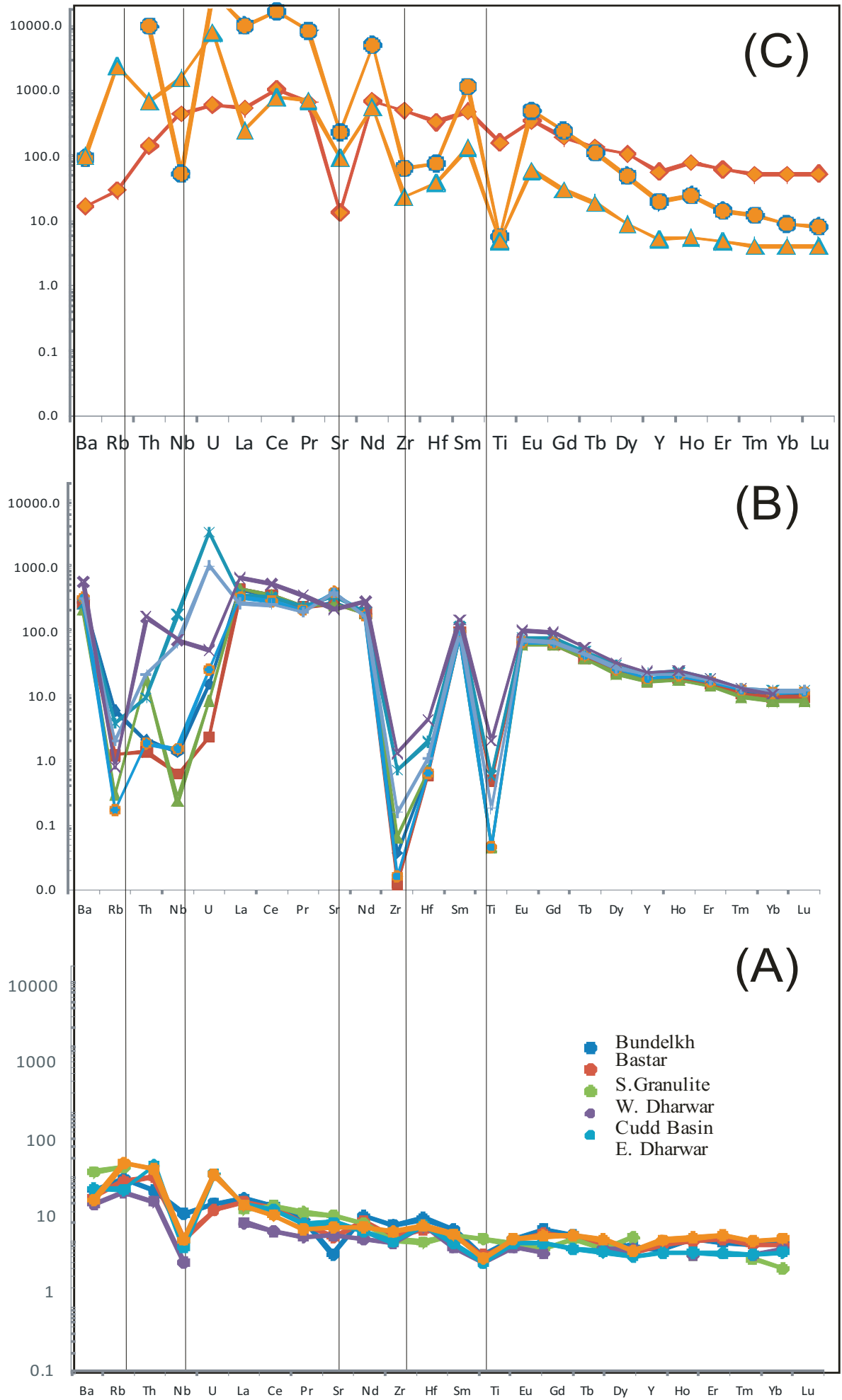

Figure 9: Least fractionated Palaeoproterozoic mafic igneous compositions (A) in comparison with (B) compositional variants of Indian carbonatites (Ackerman et al., 2017) and (C) transition zone carbonatite composition (Walker et al., 2008). Values normalized to primordial mantle values (Sun and McDonough, 1989).

agreement with crustal residence ages ( $\mathrm{T}_{\mathrm{DM}}$ model ages) of $2.87 \pm 0.08$ Ga estimated from the Palaeoproterozoic igneous units in south India and also with the model ages reported for the 2.1 Ga old Gwalior traps and for the $2.7 \mathrm{Ga} \mathrm{BD} 1$ dykes in Bastar craton. The only exception is the model ages from $1.88 \mathrm{Ga}$ BD2 dyke intrusions that 
have yielded significantly lower model ages from rest of the data. These results are perfectly consistent with the suggestion that this age ( 2.9 Ga) marks the timing of processes associated with the formation and emplacement (underplating) of the SCLM that is some 0.6 to $1.0 \mathrm{Ga}$ prior to the Palaeoproterozoic igneous activity. Coincidence of this age with many residence ages near 3.0 Ga from the granulite crustal rocks of the Nilgiri massif (Peucat et al 1989) and 3000-2900 Ma trondhjemite plutonic activity in India (for example, Naqvi and Rogers, 1987; p. 19; Radhakrishna and Ramakrishnan, 1993) suggest that the SCLM formation under the Indian shield is synchronous with a major crustal stabilization event. Similarly, simultaneous formation of SCLM and basement stabilization much prior to the Palaeoproterozoic igneous activity is known from Precambrian terrains elsewhere (the Kaapvaal craton in South Africa: Marsh et al., 1989; Lewisian complex in Scotland: Waters et al., 1989). Furthermore, this age is marked broadly by the timing of stabilization of lithosphere and significant changes in Earth behavior (Cawood et al., 2018).

A voluminous hydrous lithospheric mantle across the cratons appears to have developed during the Archaean ( 3 Ga), and it has contributed significantly to the Palaeoproterozoic magmas. Despite broad similarities with tholeiitic composition, there exist some subtle differences in the enriched characteristics and some of the incompatible element ratios. For example, at least two subgroups of magmas were identified in the Palaeoproterozoic mafic dyke samples of the Bundelkhand (Radhakrishna et al., 2019). However, more striking is the absence of Fe-rich noritic magmatism that marked the significant Palaeoproterozoic magmas of the Scourie dykes in Lewisian complex (Weaver and Tarney, 1981) and the Ferro-picrite occurrences, which are widespread in many Archaean cratons during Neoarchaean, in the large volumes of Palaeoproterozoic magmas in the Indian shield. Does it anyway relate to the supercontinental configurations during that time or does it indicate heterogeneities were distributed throughout the early Proterozoic-Late Archaean mantle (for example, Milidragovic et al., 2014), or such Fe-rich domains, if any, under the Indian shield were exhausted during the Neoarchaean melting as suggested by Milidragovic et al. (2016).

\section{Thermal Constraints}

Two significant features of Palaeoproterozoic mafic igneous activity- the widespread distribution indicating large volumes of magma generation and apparent occurrence of each magma pulse within a narrow time bracket- require enough thermal energy to generate the mantle melts and to turn-on and turn-off the thermal tap very quickly. It has been common to appeal to mantle plumes to supply this energy for melting in spite of divergent views on the mechanism (White and McKenzie, 1989; Griffiths and Campbell, 1990; Richard et al., 1989). It may be noted that the Palaeoproterozoic magmas of the Indian shield and elsewhere share common geochemical characteristics (enrichment of LILE and LREE; Nb and Ta depletion) with the Phanerozoic continental flood basalts that are mantle plume derived. The main distinction is that the Phanerozoic continental flood basalts occur as widespread extrusives whereas the Palaeoproterozoic magmas emplaced mainly as dyke intrusions without large associated extrusives. Although giant dyke swarms are known to be feeders for many plateau basalts, the absence of extrusive pulses during the Palaeoproterozoic magmatism appears real and not an artifact of erosion. The differences between mode of emplacement of
Phanerozoic (with large extrusive pulses) and Palaeoproterozoic (with little or no extrusive magmas) mafic magmas may have some implications for the depths of origin of the mantle plumes. The mantle plumes for the continental flood basalts might have their origin at greater depths, at the CMB (core mantle boundary) and developed large head diameters (>1000 km; White and McKenzie, 1989) on arrival at the base of the lithosphere resulting in large-flood volcanism. On the other hand, the Palaeoproterozoic magmas may have formed from plumes of shallow origin at $670 \mathrm{~km}$ depth and lack sufficiently large thermal energy and caused only lithosphere attenuation and the crustal fractures filled with magmas that are manifested largely as dyke intrusions. Such an interpretation is consistent with the experimental results of Griffith and Campbell (1990). However, the mantle potential temperatures estimated by the geochemical modeling of Cuddapah igneous rocks (Anand et al., 2003) do not indicate major thermal anomaly supporting a passive rifting model. Resolution of these issues becomes the focus for future studies.

\section{Conclusions}

1. Palaeoproterozoic mafic magmatism is widespread in the Indian Shield and mostly emplaced as dyke intrusions and seldom as traps in the Proterozoic sedimentary basins. It is seen as almost exclusive mafic magmatism with little felsic rock association.

2. U-Pb ages coupled with palaeomagnetic results identified at least four discrete Palaeoproterozoic igneous events at 2.362.37 Ga, 2.1-2.2 Ga, 2.1-2.0 Ga 1.99-1.89 Ga and probably two other events at about $2.4 \mathrm{Ga}$ and $1.8 \mathrm{Ga}$.

3. All the Palaeoproterozoic magmas are sub-alkaline tholeiitic in composition with enrichment of large ion lithophile and light rare earth elements. Their alkaline counterparts are virtually absent.

4. The geochemical variation in the Palaeoproterozoic mafic magmas can be explained by simple fractional crystallization. Effects of crustal assimilation are shown by very few samples.

5. Sub-Continental Lithosphere Mantle (SCLM) seems to be the major contributor of the enriched geochemistry of the Palaeoproterozoic mafic magmas emplaced in the Indian Shield. Raising mantle plumes may have supplied the material and thermal energy for the initiation of melting; however, passive rifting is an alternative explanation that needs to be examined further.

6. SCLM contribution as an overprint on asthenosphere melts is very evident in the geochemistry of the Palaeoproterozoic magmas.

7. The SCLM beneath the Indian Shield was possibly enriched by addition of fluids/melts of deep mantle origin. Amphibole seems to be the major host for the enriched components.

8. We speculate that the major segments of the Indian SCLM were generated in the early part of the earth history at around $3 \mathrm{Ga}$ and are linked to the major crustal building activity in the Indian shield.

\section{Acknowledgements}

The work is supported by the grants from the Department of Science and Technology, Government of India to TR (SR/S4/ES-598/ 
2011) and KVK (EMR/2014/000779), and also forms a part of CSIRES scheme to TR (21(1041)/17/EMR-II) and UGC-SAP scheme at the SRTM University (No. F.550/3/DRS-II/2016/SAP-I). The Director, NCESS, Trivandrum and the GITAM University, Bangalore have kindly provided facilities for this work.

\section{References}

Ackerman, L., Magma, T., Rapprich, V., Upadhyay, D., Krátký, O., Èejková, B., Erban, V., Kochergina, V.Y., and Hrska, T., 2017, Contrasting petrogenesis of spatially related carbonatites from Samalpatti and Sevattur, Tamil Nadu, India. Lithos, v. 284-285, pp. 257-275.

Agashev, A.M., Ionov, D.A., Pokhilenko, N.P., Golovin, A, V., Cherepanova, Y., and Sharygin, I.S., 2013, Metasomatism in lithospheric mantle roots: constraints from whole-rock and mineral chemical composition of deformed peridotite xenoliths from kimberlite pipe Udachnaya, Lithos, v. 160-161, pp. 201-215.

Anand, M., Gibson, S.A., Subbarao, K.V., Kelley, S.P., and Dickin, A.P., 2003, Early Proterozoic melt generation processes beneath the intra-cratonic Cuddapah Basin, southern India.Journal of Petrology, v.44, pp.2139-2171.

Arndt N.T., Christensen, U., 1992, The role of lithospheric mantle in continental flood volcanism: thermal and geochemical constraints. Journal of Geophysical Research,v. 97,pp. 10967-10981.

Baker, M.B., and Wyllie, P.J., 1992, High-pressure apatite solubility in carbonate-rich liquids: implications for mantle metasomatism: Geochimica et Cosmochimica Acta, v. 56, pp. 3409-3422.

Brey, G.P., Bulatov, V.K., Girnis, A.V., and Lahaye, Y., 2008, Experimental melting of carbonated peridotite at 6-10 GPa. Journal of Petrology, v. 49, pp. 797-821.

Campbell, I.H., 2005, Large igneous provinces and the mantle plume hypothesis. Element, v. 1, pp. 265-270.

Campbell, I.H.,and Davies, G.F., 2006, Do mantle plumes exist? Episodes, v.29, pp. 162-168.

Cawood P.A, Hawkesworth C.J, Pisarevsky S.A, Dhuime B, Capitanio F.A, Nebel O. 2018. Geological archive of the onset of plate tectonics. Phil. Trans. R. Soc. A 376: 20170405. http://dx.doi.org/ 10.1098/rsta.2017.0405

Chauvel, C., Hofmann, A.W., and Vidal, P., 1992, HIMU EM - The French Polynesian Connection: Earth and Planetary Science Letters, v. 110,pp. 99-119.

Chazot, G., Menzies, M.A., Harte, B., Mattey, D., 1994, Carbonatite metasomatism and melting of the Arabian lithosphere: evidence from oxygen isotopes and trace element composition of spinel lherzolites. Mineralogical Magazine, v. 58A,pp. 167-168.

Condie, K.C., Bobnow, D.J., and Card, K.D., 1987, Geochemistry of Precambrian mafic dykes from the southern Superior Province. In: Halls, H.C., and Fahrig, W.F. (Eds.), Mafic Dyke Swarms. GeologicalAssociation of Canada, Special Paper, 34, pp. 95-108.

Cooper, K.M., Eiler, J.M., Asimow, P.D., and Langmuir, C.H., 2004, Oxygen isotope evidence for the origin of enriched mantle beneath the mid-Atlantic ridge. Earth and Planetary Science Letters, v. 220, p. 297-316, doi: 10.1016/S0012-821X(04)00058-5.

Crawford, A.R., and Compston, W., 1970, The age of Vindhyan system of peninsular India. Quarterly Journal of Geological Society of London, v. 125, pp. 351-371.

Daniels, L.R.M., and Gurney, J.J., 1991, Oxygen fugacity constraints on the southern African lithosphere.Contributions to Mineralogy and Petrology, v. 97, pp. 154-161.

Damodara Reddy V, Anjanappa K, Prasad CVRK, Subba Reddy N (1995) Magnetic Properties andChemistry of Precambrian dykes from Peninsular India. In: Devaraju TC (ed) Dyke swarms
ofPeninsular India. Memoir Geol Soc Ind 33: 99-110

Dasgupta, R., Hirschmann, M.M., and Smith, N.D., 2007, Partial melting experiments of peridotite $+\mathrm{CO}_{2}$ at $3 \mathrm{GPa}$ and genesis of alkalic ocean island basalts. Journal of Petrology, v. 48, pp. 20932124.

Dash, J.K., Pradhan, S.K., Bhutani, R., Balakrishnan, S., Chandrasekaran, G., and Basavaiah, N., 2013, Paleomagnetism of ca. 2.3 Gamafic dyke swarms in the northeastern Southern Granulite Terrain, India: constraints on the position and extent of Dharwar craton in the Paleoproterozoic. Precambrian Research, v. 228, pp. 164-176.

Davies, G.F., 2005, A case for mantle plumes. Chinese Science Bulletin, v.50, pp. 1541-1554.

Davies, G.F., 2009, Effect of plate bending on the Urey ratio and the thermal evolution of the mantle. Earth and Planetary Science Letters, v. 287, pp. 513-518.

Eiler, J.M., 2001, Oxygen isotope variations of basaltic lavas and upper mantle rocks. Reviews in Mineralogy and Geochemistry, v. 43, p. 319-364, doi: 10.2138/gsrmg.43.1.319

Ernst, R.E., 2014, Large igneous provinces. Cambridge University Press, 653p, doi.org/10.1017/CBO9781139025300

Fahrig, W.E., 1987, The tectonic settings of continental mafic dyke swarms: failed arm and early passive margin. In: Halls, H.C., and Fahrig, W.E. (Eds.), Mafic Dyke Swarms. Geological Association of Canada, Special Papers, 34,pp. 331-348.

Foulger, G.R., 2005, Mantle plumes: Why the current skepticism? Chinese Science Bulletin, v. 50, pp. 1555-1560.

Foulger, G.R., Natland, J.H., Presnall, D.C., and Anderson, D.L. (Eds.), 2005, Plates, Plumes, and Paradigms. Geological Society of America, Special Papers, v. 388, 881 pp.

French, J.E., and Heaman, L.M., 2010, Precise U-Pb dating of Paleoproterozoic mafic dyke swarms of the Dharwar craton, India: implications for the existence of the Neoarcheansupercraton Sclavia. Precambrian Research,v.183, pp. 416-441.

French, J.E., Heaman, L.M., Chacko, T., and Srivastava, R.K., 2008, 1891-1883 Ma southern Bastar-Cuddapah mafic igneous events, India: a newly recognized large igneousprovince. Precambrian Research,v. 160, pp. 308-322.

Frey, F.A., and Green, D.H., 1974, The mineralogy, geochemistry, and origin of lherzolite: Geochimica et Cosmochimica Acta, v. 38, pp. 1023-1059.

Frey, F.A., Green, D.H., and Roy, S.D., 1978, Integrated models of basalt petrogenesis: a study of quartz tholeiites to olivine melilitites from South eastern Australia utilizing geochemical and experimental petrological data. Journal of Petrology,v. 19, pp. 463-513.

Frey, F.A., Suen, C.J., and Stockman, H., 1985, The Ronda high temperature peridotite: Geochemistry and petrogenesis. Geochimica et Cosmochimica Acta, v. 49, pp. 2469-2491.

Gallagher, K., and Hawkesworth, C., 1992, Dehydration melting and the generation of continental flood basalts. Nature,v. 358, pp. 57-59.

Goutham, M.R., Subbarao, kK.V, Prasad, C.V.R.K., Walsh, J.N and Damodara Reddy,V. 2011. Proterozoic Mafic Dykes from the SouthernMargin of Cuddapah Basin, India: Part 1 - Geochemistry and Petrogenesis, Ed:R.K. Srivastava: Dyke Swarms: Keys for Geodynamic Interpretation,Springer-Verlag Berlin Heidelberg, 47-71

Gregory, J.S., Harib, K.R., Liaoa, A.C.-Y., Denyszyn, S.W., and Vishwakarm, N., 2018, A 1.88 Ga giant radiating mafic dyke swarm across southern India and Western Australia, Precambrian Research, v. 308, pp. 58-74.

Grifiths, R.W., and Campbell, I.H., 1990, Stirring and structure in mantle starting plumes. Earth and Planetary Science Letters,v. 
99,pp. 66-78.

Hall, R.P., Hughes, D.J., and Tarney, J., 1990, Early Precambrian basic rocks of Greenland and Scotland. In: Hall, R.P., and Hughes, D.J. (Eds.), Early Precambrian Basic Magmatism. Blackie, Glasgow, pp. 248-272.

Halls, H.C., and Fahrig, W.E. (Eds.), 1987, Mafic Dyke Swarms. Geological Association of Canada, Special Papers, 34, 503 pp.

Halls, H.C., Kumar, A., Srinivasan, R., and Hamilton, M.A., 2007, Paleomagnetism and U-Pb geochronology of easterly trending dykes in the Dharwar craton, India: feldspar clouding, radiating dyke swarms and the position of India at $2.37 \mathrm{Ga}$. PrecambrianResearch,v. 155, pp. 47-68.

Hammond, J.G., 1986, Geochemistry and petrogenesis of Proterozoic diabase in the southern Death Valley region of California. Contributions to Mineralogy and Petrology, v. 93, pp. 312-321.

Hart, S.R., and Zindler, A., 1989,Constraints on the nature and development of chemical heterogeneities in the mantle. In: Peltier, W.R. (Ed.), Mantle Convection. Gordon and Breach, NewYork, N.Y., pp. 261-387.

Herzberg, C., 2011, Identification of source lithology in the Hawaiian and Canary Islands: implications for origins. Journal of Petrology,v. 52, pp. 113-146.

Hirschmann, M.M., Kogiso,T., Baker, M.B., and Stolper, E.M., 2003, Alkalic magmas generated by partial melting of garnet pyroxenite. Geology,v. 31, pp. 481-484.

Hofmann, A.W., and White, W.M., 1982, Mantle plumes from ancient oceanic crust. Earth and Planetary Science Letters,v. 57, pp. 421436.

Hofmann, A.W., 1997, Mantle geochemistry: The message from oceanic volcanism. Nature, v. 385, pp. 219-229.

Hughes, H.S.R., McDonald, I., Goodenough, K.M., Ciborowski, T.J., Kerr, A.C., Davies, J.H.F.L., and Selby, D., 2014, Enriched lithospheric mantle keel below the Scottish margin of the North Atlantic Craton: evidence from the Palaeoproterozoic Scourie Dyke Swarm and mantle xenoliths. Precambrian Research, v. 250, pp. 97-126.

Humphreys, E.R., and Niu, Y.L., 2009, On the composition of ocean island basalts (OIB): the effects of lithospheric thickness variation and mantle metasomatism. Lithos, v. 112, pp. 118-136.

Ionov, D.A., Dupuy, C., O’Reilly, S.Y., Kopylova, M.G., and Genshaft, Y.S., 1993, Carbonated peridotite xenoliths from Spitsbergen: implications for trace element signature of mantle carbonate metasomatism. Earth and Planetary Science Letters,v. 119, pp. 283-297.

Ionov, D.A., and Hofmann, A.W., 1995, Nb-Ta-rich mantle amphiboles and micas: implications for subduction-related metasomatic trace element fractionations. Earth and Planetary Science Letters,v. 131,pp. 341-356.

Ionov, D.A., Doucet, L.S., Carlson, R.W., Golovin, A.V., and Korsakov, A.V., 2015, Post-Archean formation of the lithospheric mantle in the central Siberian craton: Re-Os and PGE study of peridotite xenoliths from the Udachnaya kimberlite. Geochimica et Cosmochimica Acta, v. 165, pp.466-483.

Jackson, M.G., Hart, S.R., Koppers, A.A.P., Staudigel, H., Konter, J., Blusztajn, J., Kurz, M., and Russell, M.A., 2007, The return of subducted continental crust in Samoan lavas. Nature, v. 448, pp. 684-687.

Kelemen, P.B., Johnson, K.T.M., Kinzler, R.J., and Irving, A.J., 1990, High field strength element depletions in arc basalts due to mantle - magma interaction. Nature,v. 345, pp. 521-524.

Keppler, H., Wiedenbeck, M., and Shcheka, S., 2003, Carbon solubility in olivine and the mode of carbon storage in the Earth's mantle. Nature, v. 424, pp. 414-416.

Kukula, A., Puziewicz, J., Matusiak-Malek, M., Ntaflos, T., Büchner,
J., and Tietz, O., 2015, Melt metasomatism beneath NE termination of the Eger Rift (Europe): the case study of the Steinberg (Upper Lusatia, SE Germany) xenoliths. Mineralogy and Petrology, v. 109, pp. 761-787.

Kogiso, T., Hirschmann, M.M., and Frost, D.J., 2003, High-pressure partial melting of garnet pyroxenite: possible mafic lithologies in the source of ocean island basalts. Earth and Planetary Science Letters,v. 216, pp. 603-617.

Krishna Brahmam, N., and Dutt,N.V.B.S., 1992, A meteoritic impact theory for the initiation of the Cuddapah (Proterozoic)Basin of India. Bulletin Indian Geologists’ Association, v.25 (1-2), pp.360.

Kumar, A.,Nagaraju, E., Besse, J., and Bhaskar Rao, Y.J., 2012, New age, geochemical and palaeomagnetic data on a 2.21 Ga dyke swarm from south India: constraints on Paleoproterozoic reconstruction. Precambrian Research,v. 220-221, pp. 123-138.

Kumar, A., Parashuramulu, V., and Nagaraju, E., 2015, A 2082 Ma radiating dyke swarm in the eastern Dharwar craton, southern India and its implications to Cuddapah basin formation. Precambrian Research, v. 266, pp. 490-505.

Kumar, A., Parashuramulu, V., Shankar, R., and Besse, J., 2017, Evidence for a Neoarchean LIP in the Singhbhum craton, eastern India: implications to Vaalbara supercontinent, Precambrian Research, v. 292, pp. 163-174.

Kyser, K.T., 1990, Stable isotopes in the continental lithospheric mantle.In:Menzies, M.A. (Ed.), ContinentalMantle: Oxford, Larendon Press, p. 67-86.

LeCheminant, A.N., and Heaman, L.M., 1989,Mackenzie igneous events, Canada: middle Proterozoic hotspot magmatism associated with ocean opening. Earth and Planetary Science Letters, v. 96,pp. 38-48.

Leelanandam, C., Burke, K., Ashwal, L.D., and Webb, S., 2006, Proterozoic mountain building in Peninsular India: an analysis based primarily on alkaline rock distribution. Geological Magazine, v. 143, pp. 195-212.

Le Maitre, R.W., 2002, Igneous Rocks: A Classification and Glossary of Terms: Recommendations of the International Union of Geological Sciences Subcommission on the Systematics of Igneous Rocks: Cambridge, Cambridge University Press, 236 p.

Lyubetskaya, T., and Korenaga, J., 2007, Chemical composition of Earth's primitive mantle and its variance: 1 . Method and results. Journal of Geophysical Research, v. 112, p. B03211, doi:10.1029/ 2005JB004223

Marsh, J.S., Bowen, M.P., Rogers, N.W., Bowen, T.B., 1989, Volcanic rocks of the Witwatersrand Triad, South Africa. II. Petrogenesis of mafic and felsic rocks of the Dominion Group. Precambrian Research,v. 44, pp. 39-65.

Meert, J.G., Pandit,M.K., and Pradhan, V.R., 2011, Preliminary report on the paleomagnetismof $1.88 \mathrm{Ga}$ dykes fromthe Bastar and Dharwar cratons, Peninsular India. Gondwana Research, v. 20, pp. 335-343.

Menzies, M.A., 1983, Mantle ultramafic xenoliths in alkaline magmas: evidence for mantle heterogeneity modified by magmatic activity. In:Continental Basalts and Mantle xenoliths edited by Hawkesworth, C.J., Norry, M.J., Shiva, Nantwich, pp. 92-110.

Menzies, M., and Murthy, V.R., 1980, Mantle metasomatism as a precursor to the genesis of alkaline magmas - isotopic evidence. American Journal of Science, v. 280A, pp. 622-638.

Menzies, M.A., and Hawkesworth, C.J. (Eds.), 1987, Mantle Metasomatism: Academic Press, London, Geology Series.

McKenzie, D., and O'Nions, R.K., 1995, The source regions of oceanic island basalts. Journal of Petrology, v. 36, pp. 133-159.

Milidragovic, D., Francis, D., Weis, D., and Constantin, M., 2014, Neoarchean (c. 2.7 Ga) plutons of the Ungava Craton, Quebec, 
Canada: parental magma compositions and implications for Ferich mantle source regions. Journal of Petrology, v. 55, pp. 24812511.

Milidragovic, D., and Francis, D., 2016, Ca. 2.7 Ga ferropicritic magmatism: a record of Fe-rich heterogeneities during Neoarchean global mantle melting. Geochimica et Cosmochimica Acta, v. 185, pp. 44-63. doi:10.1016/j.gca.2015.09.023

Mishra, D.C. and Tiwari, V.M., 1995,An asymmetrical basic lopolith below sediments in western Cuddapah basin-geophysical evidence. Proc. Annual Convention of Geological Society of India, pp. 31-41.

Marsh, J.S., Bowen, M.P., Rogers, N.W., and Bowen, T.B., 1989, Volcanic rocks of the Witwatersrand Triad, South Africa. II. Petrogenesis of mafic and felsic rocks of the Dominion Group. Precambrian Research,v. 44, pp. 39-65.

Mondal, M.E.A., and Ahmad, T., 2001, Bundelkhand mafic dykes, central Indian shield: implications for the role of sediment subduction in Proterozoic crustal evolution. The Island Arc, v. 10, pp. 51-67.

Nagaraja Rao, B.K., Rajurkar, S.T., Ramalingaswamy, G., and Balu, B.R., 1987, Stratigraphy, structure and evolution of the Cuddapah Basin. In: Purana Basins of Peninsular India. Memoir Geological Society of India, v. 6, pp.33-86.

Naqvi, S.M., and Rogers, J.J.W., 1987, Precambrian geology of India. Oxford University Press, Oxford, p. 223.

Nielsen, T.E.D., 1987,Mafic dyke swarms in Greenland: a review. In: Halls, H.C., and Fahrig, W.F. (Eds.), Mafic Dyke Swarms. Geological Association of Canada, Special Paper, 34, pp. 349360.

Niu, Y.L., 2005, Generation and evolution of basaltic magmas: Some basic concepts and a hypothesis for the origin of the Mesozoic, Cenozoic volcanism in eastern China. Geological Journal of China Universities, v. 11, pp. 9-46.

Niu, Y.L., 2009, Some basic concepts and problems on the petrogenesis of intra-plate ocean island basalts. Chinese Science Bulletin, v. 54, pp. 4148-4160.

Niu,Y., and O’Hara, M. J., 2003, Origin of ocean island basalts: a new perspective from petrology, geochemistry, and mineral physics considerations. Journal of Geophysical Research,v. 108, B4, 2209.

Niu,Y., Wilson., M., Humphreys, E.R., andO’Hara, M.J., 2012, A trace element perspective on the source of ocean island basalts (OIB) and fate of subducted ocean crust (SOC) and mantle lithosphere (SML). Episodes, pp. 310-327.

Niu, Y.L., Collerson, K.D., Batiza, R., Wendt, J.I., and Regelous, M., 1999, The origin of E-Type MORB at ridges far from mantle plumes: The East Pacific Rise at $11^{\circ} 20^{\prime}$ : Journal of Geophysical Research, v. 104, pp. 7067-7087.

Niu, Y.L., Regelous, M., Wendt, J. I., Batiza, R., and O’Hara, M.J., 2002, Geochemistry of near-EPR seamounts: Importance of source vs. process and the origin of enriched mantle component: Earth and Planetary Science Letters, v. 199, pp. 327-345.

O’Reilly, Y.S., and Griffin, W.L., 1988, Mantle metasomatism beneath western Victoria, Australia: I, Metasomatic processes in Crdiopside lherzolites: Geochimica et Cosmochimica Acta, v. 52, pp. 433-447.

Pandey, B.K., Gupta, J.N., Sarma, K.J., and Sastry, C.A., 1997, Sm$\mathrm{Nd}, \mathrm{Pb}-\mathrm{Pb}$ and $\mathrm{Rb}-\mathrm{Sr}$ geochronology and petrogenesis of the mafic dyke swarm of Mahabubnagar, South India: implications for paleoproterozoic crustal evolution of the Eastern Dharwar Craton.Precambrian Research,v. 84, pp. 181-196.

Pandey, U.K., Sastry, D.V.L.N., Pandey, B.K., Maduparna Roy, Rawat, T.P.S., Rajeeva Ranjan and Shrivastava, V.K., 2012, Geochronological (Rb-Sr and Sm-Nd) studies on intrusive gabbros and dolerite dykes from parts of northern and central Indian cratons: implications for the age of onset of sedimentation in Bijawar and Chattisgarh Basins and uranium mineralisation, Journal of Geological Society of India, v. 79, pp. 30-40.

Patchett, P.J,, Lehnert, K., Rehkamper, M., and Sieber, G., 1994, Mantle and crustal effects on thegeochemistry of Proterozoic dykes and sills in Sweden. Journal of Petrology,v. 35, pp. 10951125.

Pearce, J.A., 2003,Supra-subduction zone ophiolites: the search for modern analogues. Special Paper of the Geological Society of America373, pp. 269-293.

Peucat, J.J., Vidal, P., Griffiths, J.B., and Condie, K.C., 1989, Sr, Nd and $\mathrm{Pb}$ isotopic systematics in the Archaean low- to high-grade transitionzone of southern India: syn-accretion vs post-accretion granulites. Journal of Geology,v. 97,pp. 537-550.

Pilet, S., Hernandez, J., Sylvester, P., and Poujol, M., 2005, The metasomatic alternative for ocean island basalt chemical heterogeneity. Earth and Planetary Science Letters, v. 236, pp. 148-166, doi:10.1016/j.epsl.2005.05.004.

Pilet, S., Baker, M. B., and Stolper, E.M., 2008, Metasomatized lithosphere and the origin of alkaline lavas. Science, v. 320, pp. 916-919, doi:10.1126/science.1156563.

Pilet, S., Baker, M.B., Muntener, O., and Stolper, E.M., 2011, Monte Carlo simulations of metasomatic enrichment in the lithosphere and implications for thesource of alkaline basalts. Journal of Petrology, v. 52, pp. 1415-1442.

Pisarevsky, S.A., Biswal, T.K., Wang, X.-C., De Waele, B., Ernst, R., Söderlund, U., Tait, J.A., Ratre, K., Singh, Y.K., and Cleve, M., 2013, Palaeomagnetic, geochronological and geochemical study of Mesoproterozoic Lakhna Dykes in the Bastar Craton, India: implications for the Mesoproterozoic supercontinent. Lithos, v. 174, pp. 125-143.

Pivarunas, A.F., Meert, J.G., Panditb, M.K and Sinha, A. 2018. Paleomagnetism and geochronology of mafic dykes from the Southern Granulite Terrane, India: Expanding the Dharwar craton southward, Tectonophysics, https://doi.org/10.1016/ j.tecto.2018.01.024

Pradhan, V.R., Meert, J.G., Pandit, M.K., Kamenov, G., Gregory, L.C., and Malone, S.J., 2010, India's changing place in global Proterozoic reconstructions: new geochronologic constraints on key paleomagnetic poles from the Dharwar and Aravalli/ Bundelkhand cratons. Journal of. Geodynamics, v. 50, pp. 224242.

Pradhan, V.R., Meert, J.G., Pandit, M.K., Kamenov, G., and Mondal, E.A., 2012, Tectonic evolution of the Precambrian Bundelkhand craton, central India: insights from paleomagnetic and geochronologic studies on the mafic dyke swarms. Precambrian Research,v. 198-199, pp. 51-76.

Presnall, D.C., and Gudfinnsson, G.H., 2005, Carbonate-rich melts in the oceanic low-velocity zone and deep mantle. In: Foulger, G.R., Natland, J. H., Presnall, D. C., and Anderson, D.L. (Eds.), Plates, Plumes, and Paradigms. Geological Society of America Special Papers, v. 388, pp. 207-216.

Presnall, D.C., and Gudfinnsson, G.H., 2008, The origin of the oceanic lithosphere. Journal of Petrology, v. 49, pp. 615-632.

Prytulak, J., and Elliott, T., 2007, $\mathrm{TiO}_{2}$ enrichment in ocean island basalts. Earth and Planetary Science Letters, v. 263, pp. 388403.

Puziewicz, J., Matusiak-Ma3ek, M., Ntaflos, T., Grégoire, M., and $\mathrm{Kuku}^{3}$ a, A., 2015, Subcontinental lithospheric mantle beneath Central Europe. IJES. doi:10.1007/s00531-014-1134-2.

Radhakrishna, T., Pearson, D.G., and Mathai, J., 1995, Evolution of Archaean southern Indian lithospheric mantle: a geochemical study of Proterozoic Agali - Coimbatore dykes. Contributions to 
Mineralogy and Petrology, v. 121, pp. 351-363. DOI 10.1007/ s004100050101.

Radhakrishna, T., and Joseph, M., 1998, Geochemistry and petrogenesis of the Proterozoic dykes in Tamilnadu, south India: implications for the continental lithosphere. Geologische Rundschau,v.87, pp. 268-282.

Radhakrishna, T., and Ramakrishnan, M., 1993, Udupi-Kavali geotransect across south India, GlobalGeoscienceTransect, 11; co-published by the Inter-Union Commission on the Lithosphere and Geological Society of India, 18 pp.

Radhakrishna, T., Ram Chandra., Akhilesh Srivastava and Balasubramonian, G., 2013, Central Indian Bundelkhand and Bastar cratons in the Palaeoproterozoic supercontinental reconstructions: a palaeomagnetic perspective. Precambrian Research, v. 226, pp. 91-104. .doi.org/10.1016/j.precam res.2012.11.013.

Radhakrishna, T., Krishnendu, N.R., and Balasubramonian, G., 2013, Palaeoproterozoic Indian shield in the global continental assembly: evidence from palaeomagnetism of mafic dykes. Earth Science Reviews, v. 126, pp. 370-399.

Radhakrishna, T., and Joseph, M., 1996, Proterozoic palaeomagnetism of the mafic dyke swarms in the high-grade region of south India. Precambrian Research., v. 76, pp. 31-46.http://dx.doi.org/ 10.1016/0301-9268(95)00022-4.

Radhakrishna, T., Mathew Joseph, Krishnendu, N.R., and Balasubramonian, G., 2003, Palaeomagnetism of mafic dykes in the Karnataka Craton: possible geodynamic implications. Geological Society of India Memoir, v. 50, pp. 193-224.

Radhakrishna, T., Balasubramonian, G., Mathew Joseph and Krishnendu, N.R., 2004, Mantle processes and geodynamics: inferences from mafic dykes of south India. In: Earth System Science and Natural Resource Management. Centre for Earth Science Studies, Trivandrum, 3-25 pp.

Radhakrishna, T., Krishnendu, N.R., and Balasubramonian, G., 2007, Mafic dyke magmatism around the Cuddapah basin: age constraints, petrological characteristics and geochemical inference for a possible magma chamber on the southwestern margin of the basin. Journal of Geoogical Society of India, v. 70, pp. 194-206.

Radhakrishna, T., Tomson, J.K., and Ram Chand, 2019, Geochemistry of Palaeoproterozoic mafic dyke intrusions in the Bundelkhand craton, India: implications for the formation of subcontinental lithospheric mantle and its interaction with plume derived melts. Precambrian Research (submitted).

Ramakrishnan,M., Vaidyanadhan, 2008, Geology of India, vol. 1. Geological Society of India,Bangalore, 556 pp.

Rambabu, V., 1993, Basement structure of the Cuddapah Basin from gravity anomalies. Tectonophysics, v.223, pp.411-422.

Richard, M.A., Duncan, R.A., and Courtillot, V.E., 1989, Flood basalts and hotspot tracts, plume heads and tails. Science,v. 246, pp. 103107.

Ringwood, A.E., 1975, Composition and petrology of Earth's mantle. McGraw-Hill, New York, 618 pp.

Ratre, K., De Waele, B., Biswal, T.K., and Sinha, S., 2010, SHRIMP geochronology for the 1450 Ma Lakhna dyke swarm: its implication for the presence of Eoarchaean crust in the Bastar Craton and 1450-517 Ma depositional age for Purana basin (Khariar), Eastern Indian Peninsula. Journal of Asian Earth Sciences,v. 39, pp. 565-577.

Roy, A., Sarkar, A., Jeyakumar, S., Aggrawal, S. K., \& Ebihara, M. 2002. Mid-Proterozoic plume-related thermal event in eastern Indian craton: evidence from trace elements, REE geochemistry and Sr-Nd isotope systematics of basic-ultrabasic intrusives from Dalma volcanic belt. Gondwana Research, v. 5(, pp. 133-146

Rudnick, R.L., Gao, S., 2003, The composition of the crust. In:
Rudnick, R.L. (Ed.), The Crust. Treatise on Geochemistry 3, 164.

Sensarma, S., H Palme, H \& Mukhopadhyay, D. 2002. Crust-mantle interaction in the genesis of siliceous high magnesian basalts: evidence from the Early Proterozoic Dongargarh Supergroup, India. Chemical Geology 187 (1-2), 21-37

Sheraton, J.W., Black, L.P., McCulloch, M.T., and Oliver, R.L., 1990,Age and origin of a compositionally varied mafic dyke swarm in the Bunger Hills, East Antarctica. Chemical Geology, v. 85,pp. 215-246.

Shankar, R., Vijayagopal, B., and Kumar, A., 2014, Precise Pb-Pb baddeleyite ages of 1765 Ma for aSinghbhum 'newer dolerite' dyke swarm. Current Science,v. 106, pp. 1306-1310.

Sobolev, A.V., Hofmann, A.W., Sobolev, S.V., and Nikogosian, I.K., 2005,An olivine-free mantle source of Hawaiian shield basalts. Nature, v. 434, pp. 590-597.

Sobolev, A.V., Hofmann, A.W., Kuzmin, D.V., Yaxley, G.M., Arndt, N.T., Chung, S.-L., Danyushevsky, L.V., Elliott, T., Frey, F.A., Garcia, M.O., Gurenko, A.A., Kamenetsky, V.S., Kerr, A.C., Krivolutskaya, N.A., Matvienkov, V.V., Nikogosian, I.K.,Rocholl, A., Sigurdsson, I.A., Sushchevskaya, N.M., and Teklay, M., 2007, The amount of recycled crust in sources of mantle-derived melts. Science,v. 316, pp. 412-417.

Samom, J.D., Ahmad, T., and. Choudhary, A.K., 2018, Geochemical and Sm-Nd isotopic constraints on the petrogenesis and tectonic setting of the Proterozoic mafic magmatism of the Gwalior Basin, central India: the influence of Large Igneous Provinces on Proterozoic crustal evolution. In SENSARMA, S. and STOREY, B.C. (Eds.) Large Igneous Provinces from Gondwana and Adjacent Regions. Geological Society of London, Special Publications, v. 463, pp. 243-268.

Srikantia, S.V., 1984, Kuppalapalle volcanics- a distinct upper Papaghni volcanic activity in the Cuddapah basin. Journal GeologicalSociety of India, v.25, pp.775-779.

Srivastava, R.K., Söderlund, U., Ernst, R.E., Mondal, S.K and Samal, A.K. 2019, Precambrian mafic dyke swarms in the Singhbhum craton (eastern India) and their links with dyke swarms of the eastern Dharwar craton (southern India), Precambrian Research (2018), doi: https://doi.org/10.1016/j.precamres.2018.08.001

Srivastava, R.K., and Gautam, G.C., 2015, Geochemistry and petrogenesis of Paleo-Mesoproterozoic mafic dyke swarms from northern Bastar craton, central India: Geodynamic implications in reference to Columbia Supercontinent. Gondwana Research, v. 28, pp. 1061-1078.

Srivastava, R.K., Ellam, Rob, M., and Gautam, G.C., 2009, Sr-Nd isotope geochemistry of the earlyPrecambrian sub-alkaline mafic igneous rocks from the southern Bastar craton, Central India. Mineralogy and Petrology,v.96, pp. 71-79.

Srivastava, R.K., Samal, A.K., Gautam, G.C., 2015, Geochemical characteristics and petrogenesis of four Palaeoproterozoic mafic dyke swarms and associated large igneous provinces from the eastern Dharwar craton, India. International Geological Review, v. 57, pp. 1462-1484.

Srivastava, R.K., Pimentel, M.M., and Gautam, G.C., 2016b, Ndisotope and geochemistry of an early Palaeoproterozoic high-Si high-Mg boninite-norite suite of rocks in the southern Bastar craton, central India: petrogenesis and tectonic significance. International Geological Review,v. 58, pp. 1596-1615.

Sun, S.S., and McDonough, W.F., 1989, Chemical and isotopic systematics of oceanic basalts: implications formantle compositions and processes. In: Saunders, A.D., and Norry, M.J. (Eds.), Magmatism in Ocean Basins. Geological Society Special Publication, v. 42, pp. 313-345.

Takazawa, E., Frey, F.A., Shimizu, N., and Obata, M., 2000, Whole 
rock compositional variations in an upper mantle peridotite (Horoman,Hokkaido, Japan): Are they consistent with a partial melting process? Geochimica et Cosmochimica Acta, v. 64, pp. 695-716.

Talat Ahmad, Deb, M., Tarney, J., and Raza, M., 2008, Proterozoic mafic magmatism in the Aravalli-Delhi Orogen, North-western India: geochemistry and tectonic framework. Journal Geological Society of India, v. 72, pp. 93-111.

Tarney, J., 1992, Geochemistry and significance of mafic dyke swarms in the Proterozoic. In: Condie, K.C. (Ed.), Proterozoic crustal evolution. Elsevier, Amsterdam, pp. 151-179.

Trela, J., Vidito, C., Gazela, E., Herzberg, C., Class C., Whalen, W., BrianJicha, Bizimise, M., and Alvarado, G.E., 2015,Recycled crust in the Galápagos Plume source at 70 Ma: implications for plume evolution. Earth and Planetary Science Letters,v. 425, pp. 268277.

Vijaya Kumar, K., Ernst, W.G., Leelanandam, C., Wooden, J.L., and Grove, M.J., 2010, Geochronologic-geochemical documentation of a Paleoproterozoic suprasubduction-zone ophiolite from Kandra, SE India. Tectonophysics, v. 487, pp. 22-32.

Vijaya Kumar, K., Laxman, B. More and Nagaraju, K., 2018, Mantle Source Heterogeneity in Continental Mafic Large Igneous Provinces: Insights from the Panjal, Rajmahal and Deccan Basalts, India. In: SENSARMA, S. and STOREY, B.C. (Eds.), Large Igneous Provinces from Gondwana and Adjacent Regions. Geological Society, London, Special Publications, v. 463, pp. 87115.

Vijaya Kumar, K., Rathna, K., and Leelanandam, C., 2015, Proterozoic subduction-related and continental rift-zone mafic magmas from the Eastern Ghats Belt, SE India: geochemical characteristics and mantle sources. Current Science, v. 108, pp. 184-197.

White, B.S.,and Wyllie, P.J., 1992, Phase relations in synthetic

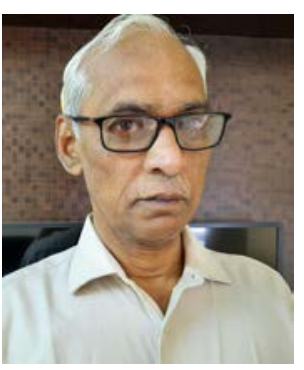

T. Radhakrishna did his Ph.D on petrology and tectonic significance of Indus suture ophiolites in Dras area at the National Geophysical Research Institute, Hyderabad and then was a scientist at National Centre for Earth Science Studies, Trivandrum, India for over three decades. Currently he is a CSIR- Emeritus Scientist at GITAM University, Bangalore. He is elected as a Fellow of the Indian Academy of Sciences. His research focused on petrology and palaeomagnetism of mafic igneous rocks in India to understand mantle processes and geodynamics of the Indian shield. He has been associated as an Indian counter part with many IGCP-projects. lherzolite- $\mathrm{H}_{2} \mathrm{O}-\mathrm{CO}_{2}$ from 20-30 kb, with applications to melting and metasomatism. Journal of Volcanology and Geothermal Research, v. 50, pp. 117-130.

Walter, M.J., Bulanoa, G.P., Armstrong, L.S., Keshav, S., Blundy, J.D., Gudfinnsson, G., Lord, O.T., Lennie, A.R., Clark, S.M., Smith, C.B., and Gobbo, L., 2008, Primary carbonatite melt from deeply subducted oceanic crust. Nature, v. 454, pp. 622-626.

Waters, E.G., Cohen, A.S., O’Nions, R.K., and O'Hara, M.J., 1990,Development of Archaean lithosphere deduced from chronology and isotope chemistry of Scourie Dykes. Earth and Planetary Science Letters, v. 97,pp. 241-255.

Weaver, B.L., and Tarney, J., 1981, The Scourie dyke suite: petrogenesis and geochemical nature of the Proterozoic subcontinental mantle. Contributions to Mineralogy and Petrology, v. 78,pp. 175-188.

White, W.M., and Duncan, R.A., 1996, Geochemistry and geochronology of the Society Islands: New evidence for deep mantle recycling: American Geophysical Union Geophysical Monograph, v. 95, pp. 183-206.

White, R.S., and McKenzie, D.P., 1989,Magmatism at rift zones: the generation of volcanic continentalmargins and flood basalts. Journal of Geophysical Research, v. 94, pp. 7685-7730.

Yaxley, G.M., Green, D.H., and Kamenetsky, V., 1998, Carbonatite metasomatism in southern Australia lithosphere. Journal of Petrology, v.39, pp. 1917-1930.

Yellur, D.D.. 1977. Geochemical clues in the investigation of the tectonic environment of the Dalma greenstones, Bihar, India. Chemical Geology, v. 20. pp. 345-363.

Zachariah, J.K., Hanson, G.N., and Rajamani, V., 1995, Postcrystallization disturbance in the neodymium and lead isotope systems of metabasalts from the Ramagiri schist belt, southern India. Geochimica et Cosmochimica Acta,v. 59, pp. 3189-32.

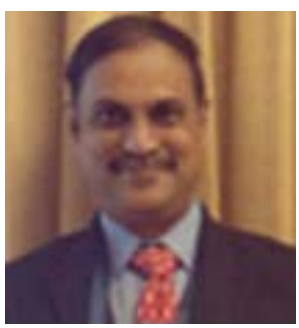

K. Vijaya Kumar is presently working as a Professor in the School of Earth Sciences at the SRTM University, Nanded, India. He earned his M.Sc. in Geology and Ph.D. in Geochemistry from Osmania University, Hyderabad before joining the faculty at the SRTM University. His research interests include understanding the mantle and crustal processes in varied tectonic regimes by using principles of geochemistry. His ongoing studies include 1) evaluation of the tectonothermal history of the Eastern Ghats Belt, 2) Precambrian sutures of India and their roles in the geological development of the subcontinent, 3) cumulus processes within the layered magma chambers, 4) magma chamber and mantle processes in the origin of flood-basalt provinces, 5) elemental behavior during mantle melting and 6) geochemistry of sediments and crustal evolution. 